\title{
DENTINGH
}

\section{Innovative Design of New Geothermal Generating Plants}

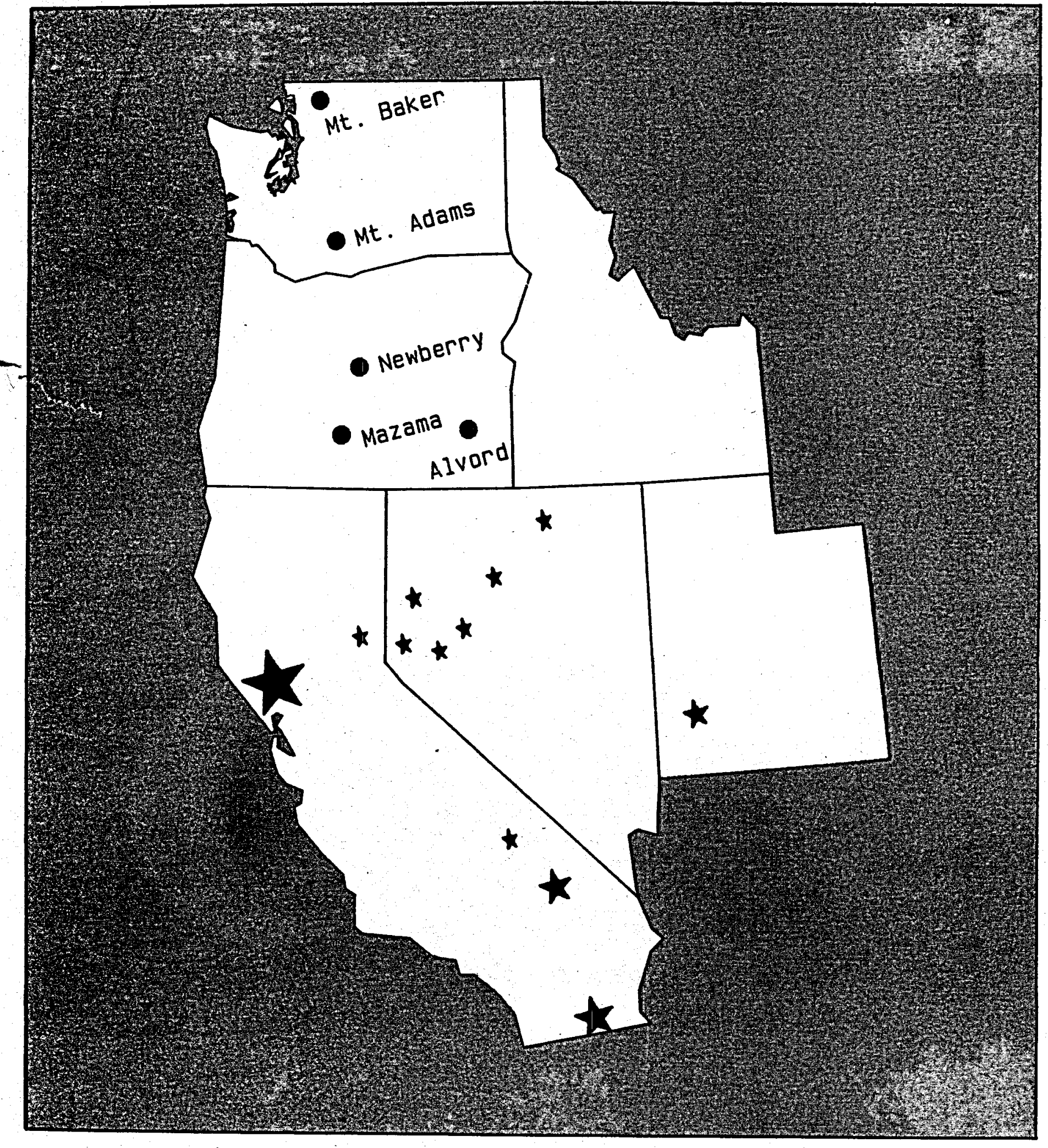




\section{DISCLAIMER}

This report was prepared as an account of work sponsored by an agency of the United States Government. Neither the United States Government nor any agency Thereof, nor any of their employees, makes any warranty, express or implied, or assumes any legal liability or responsibility for the accuracy, completeness, or usefulness of any information, apparatus, product, or process disclosed, or represents that its use would not infringe privately owned rights. Reference herein to any specific commercial product, process, or service by trade name, trademark, manufacturer, or otherwise does not necessarily constitute or imply its endorsement, recommendation, or favoring by the United States Government or any agency thereof. The views and opinions of authors expressed herein do not necessarily state or reflect those of the United States Government or any agency thereof. 


\section{DISCLAIMER}

Portions of this document may be illegible in electronic image products. Images are produced from the best available original document. 


\section{Supplement \\ Innovative Design of New Geothermal Generating Plants}

For Limited Distribution

Internal Use Only

Prepared by:

R. Gordon Bloomquist, Ph.D.

Washington State Energy Office

John D. Geyer

Bonneville Power Administration

B. Alexander Sifford III

Oregon Department of Energy 


\section{Acknowledgements}

This assessment of state-of-the-art geothermal technology and financing reflects the work of many individuals and groups, and could not have been completed without their full cooperation and support.

The authors would like to express their appreciation and give special recognition to the many firms and individuals who gave so freely of their time and also provided us with the information which made this report possible.

Special appreciation is expressed to Stone and Webster Engineering for all of their cooperation, assistance, and guidance in making the right contacts and in providing so much detailed information on the facilities which they have designed or bave otherwise been associated with.

\section{Disclaimer}

This report was prepared expressly for use by the Bonneville Power Administration. Neither the Bonneville Power Administration nor the United States Department of Energy, nor any of their employees, nor any of their contractors, subcontractors, or their employees, makes any warranty, expressed or implied, or assumes any legal liability or responsibility for the accuracy, completeness, or usefulness of any information presented. The views and opinions of authors expressed herein do not necessarily state or reflect those of the United States Government or any agency thereof. Reference herein to any specific product, process, or service by trade name, mark, manufacturer, or otherwise, does not necessarily constitute or imply its endorsement or recommendation or favoring by the United States Govemment or any agency thereof. 


\section{Table of Contents}

Preface $v$

Introduction 1

Chapter 1

Market Influences on Power Development 3

Introduction 3

Energy Climate 3

California 4

Nevada 6

Utah 7

Oregon 8

Washington 10

Chapter 2

Design Innovations for Efficiency and Reliability 13

Introduction 13

PURPA Influence on Contemporary Geothermal Plants 14

Plant Design 14

Plant Development 16

Plant Operation 17

Increased Efficiency 17

Introduction 17

The Geysers Case Studies 17

SMUDGEO \#1 17

Santa Fe \#1 18

NCPA \#1 19

Non-Geysers Case Histories 19

Heber Binary 19

Mammoth-Pacific 20

ORMESA I 20

Desert Peak 20

Conclusion 21

Availability Through Innovation 21

Introduction 21

Case Histories 21

Santa Fe \#1 21

ORMESA I 22

Coso 22

Northem California Power Agency Geothermal Plants \#1 and \#2 22

Conclusion 23 . 


\section{Table of Contents}

Reducing Environmental Impacts 23

Introduction 23

Reducing Impacts of Airbome Pollutants 23

Reducing Impacts Upon Water 25

Improved Land Use 25

Reducing Visual Impacts 26

Conclusion 26

Chapter 3

Financing: The Banker's Perspective 29

Introduction 29

Construction 29

Developers 29

Engineers 29

Equipment 29

Financing 29

Power Sales 29

Fuel Supplies 30

Financiers Emphasis on Operation and Maintenance 31

Regulation 32 .

Financiers of Geothermal Energy Projects 33

Introduction 33

Common Elements 34

Individual Perspectives 35

Bankers Trust Company 35

Union Bank of Switzerland 35

Swiss Bank Corporation 36

Citibank 36

General Electric Capital 36

Credit Suisse 37

Conclusions 37

References 39 


\section{Tables and Figures}

Table 1 Existing $1980 \mathrm{MW}(\%) \quad 4$

Table 2 Federal Leases in Effect (acreage) 8

Table 3 Geothermal Plant Data Matrix 15

Table $4 \quad$ Alternate Energy Financings 34

Figure 1 New Western States Geothermal Plants 14

Figure 2 Four-Casing Quadruple-Flow 18

Figure 3 Two-Casing Double-Flow 18

Figure 4 Binary Cycle Power Plant 19 


\section{Preface}

These case studies are part of a capability building exercise for the Bonneville Power Administration (BPA), the Washington State Energy Office (WSEO), and the Oregon Department of Energy (ODOE). The contents represent company confidential materials voluntarily provided during interviews conducted over the period 1987-1989.

The work was sponsored to develop a common understanding by BPA of geothermal technology and industry status among technical representatives of WSEO, ODOE, and BPA.

Information is drawn from field interviews, industry literature, project reviews, and technical presentations, and is provided as presented.

The information is presented without warranty by the authors as to its accuracy. 


\section{Introduction}

The development of the geothermal power industry in the United States has undergone what many consider to be a revolution in technology, development, and acceptance by the financial and utility communities. Geothermal is no longer a one technology industry centered in The Geysers of northem California. It is, instead, a main supplier of electrical energy throughout California and experiencing rapid growth in Nevada and Utah. In fact, geothermal power generation is rapidly becoming the alternative energy of choice for many utilities out pacing wind, solar, biomass, and even cogeneration in areas where available.

Recent trends in geothermal development are, to a large extent, a reflection of the growing and maturing independent power industry, a direct result of PURPA implementation. Geothermal provides the independent power production with a cost-effective means of meeting utility demand with plants which are becoming more and more energy efficient and which exhibits outstanding capacity and availability. The track record established by the geothermal industry over the past decade has eased the fears of financiers, utilities, and utility regulators, and established geothermal as a major contender for future utility acquisition of power throughout the west.

The findings presented in this report are the result of site visits and interviews with plant owners and operators, representatives of major financial institutions, utilities involved with geothermal power purchases and/or wheeling. Information so obtained was supported by literature research and data supplied by engineering firms who have been involved with designing and/or construction of a majority of he plants visited. The interviews were conducted by representatives of the Bonneville Power Administration, the Washington State Energy Office, and the Oregon Department of Energy during the period 1986-1989. 


\section{Chapter 1}

\section{Market Influences On Power Development}

\section{Introduction}

A large number of electrical generation facilities have been built in the far westem states since 1980 by utilities and independent power producers. Some states have witnessed the creation of large amounts of new power by non-utility developers, e.g., California. Other states such as Washington have seen only minor amounts of non-utility power come on-line. In those states with both a need for power and the availability of geothermal resources, many small, often "pilot," geothermal plants have been built by both utilities and independent energy producers.

This chapter analyzes particular circumstances surrounding development of the most recent geothermal power plants built in California, Nevada, and Utah. In addition, economic and regulatory factors affecting pilot plant viability, local issues critical to development, and current legislative and administrative issues affecting power production and geothermal resource development in California, Nevada, and Utah are examined in detail. The same issues in Oregon and Washington are then compared to the states with geothermal plants on-line.

\section{Energy Climate}

The energy climate may be defined as the economic and regulatory conditions affecting energy development in a particular area or, in the case of this study, individual states. The energy climate varies by region and state. In the Pacific Northwest, large hydroelectric projects were built decades ago on the Columbia River system. Nearly all the dams were federally financed and are still federally operated. The result is less expensive electricity than in any other region of the country. Not only is electricity inexpensive bere (about $\$ .05$ per retail kWh), but many Oregon, Washington, Idaho, and Montana utilities now have surpluses of electricity expected to last into the mid $1990 \mathrm{~s}$. With additional electricity still available for purchase from the Bonneville Power Administration at a wholesale rate of 1.5 to 2.5 cents $/ \mathrm{kWh}$, utilities are willing to pay very little for new power-about $\$ .04$ per KWh. Power is inexpensive because of the large hydroelectric generation base which BPA is able to blend with new sources of electricity. The present power surplus situation in the Pacific Northwest coupled with low avoided cost (the cost of adding new capacity) discourages the development of new generation projects.

In states neighboring the Pacific Northwest, the energy situation is different. Table 1 shows the electric supply sources by state in 1980 . The mix of sources dictated energy economics in the respective states at that time, and set the stage for developments of the last eight years. The proportional mix of energy sources remain the same today. Califomia, Nevada, and Utah have high electrical costs due to heavy dependence on large fossil and/or nuclear plants. In these states, energy prices are generally over $\$ .06$ per $\mathbf{k W h}$ including capacity payments. Until very recently, those states were also experiencing a deficit in generating capacity. Because of this, utilities were willing to pay as high as \$.10 per $\mathrm{kWh}$ or more for new sources of power. As a result of the favorable market conditions in these states, geothermal power plants have come on-line at a rapid pace.

One factor common to the development of additional generation capacity in all states is the Public Utility Regulatory Policies Act of 1978 (PURPA)(P.L. 95-617). This act requires electric utilities to purchase power from qualifying facilities, including geothermal power plants, at a price equal to the utilities' alternative cost of new power. This price is known as avoided cost. State utility commissions and regulated utilities are required by PURPA to establish terms for avoided cost purchases. According to some interpretations of the law, non-regulated utilities and federal agencies are also required to establish terms for avoided costs purchases. The manner in which each state utility commission implemented PURPA, combined with potential electric supply sources, established the energy climate. (For a full discussion of the effects of PURPA on geothermal power plants, see Sifford, Bloomquist, and Geyer, 1987.) (For a discussion of PURPA and its affects on new power generation in Oregon and Washington, see Bain, 1989; Washington State Energy Office, 1989.) 
Table 1

Exlsting $1980 \mathrm{MW}(\%)$

\begin{tabular}{|c|c|c|c|c|c|c|c|c|c|c|c|c|c|c|}
\hline \multirow{2}{*}{$\overline{\text { Coal }}$} & \multicolumn{2}{|c|}{ OR } & \multicolumn{2}{|c|}{ WA } & \multicolumn{2}{|c|}{10} & \multicolumn{2}{|c|}{ uT } & \multicolumn{2}{|c|}{ CA } & \multicolumn{2}{|c|}{ NV } & \multicolumn{2}{|c|}{ UT } \\
\hline & 530 & (5) & 1,330 & (6) & 0 & (0) & 939 & (32) & 0 & (0) & 1,978 & (53) & 2,224 & (88) \\
\hline Oil & 761 & (7) & 239 & (1) & 15 & (1) & 134 & (5) & 25,422 & (67) & 170 & (5) & 46 & (2) \\
\hline Cas & 87 & (1) & 34 & (.1) & 50 & (3) & 30 & (1) & 284 & (1) & 811 & (24) & 31 & (1) \\
\hline Hydro & 8,088 & (74) & 18,456 & (88) & 1,406 & (96) & 1,772 & (61) & 9,625 & (25) & 687 & (18) & 218 & (9) \\
\hline Nuclear & 1,216 & (11) & 860 & (4) & 0 & (0) & 0 & (0) & 1413 & (4) & 0 & (0) & 0 & (0) \\
\hline Other & 195 & (2) & 0 & (0) & 0 & (0) & 14 & (.5) & 1376 & (4) & 0 & $(0)$ & 0 & (0) \\
\hline \multicolumn{15}{|l|}{ Unit } \\
\hline TOTAL & \multicolumn{2}{|c|}{10,877} & \multicolumn{2}{|c|}{20,919} & \multicolumn{2}{|c|}{1,470} & \multicolumn{2}{|c|}{2,890} & \multicolumn{2}{|c|}{38,120} & \multicolumn{2}{|c|}{3,747} & \multicolumn{2}{|c|}{2,518} \\
\hline
\end{tabular}

Source - U.S. DOE, 1981

Another element common to all of the states is the ongoing evolution of the electric utility industry. The traditional role of utilities began changing in the early 1980 's due to several factors. One was the passage of PURPA, as already discussed. A second was a lower than anticipated in consumer demand. Low demand reduced the need for large increments of new electricity, i.e., thermal power plants, the traditional means of meeting the need for new capacity. A third factor was the decision by many state utility commissions to disallow what they considered to be imprudent investments in large (nuclear and coal) plants to be passed on to ratepayers. This had the effect of further discouraging utility investments in new generation. A fourth factor was the opportunity of utilities to diversify into unregulated businesses. Such "outside" business represents the new alternative investment opportunity for utilities.

Non-utility businesses have displaced construction of new capacity as a major means of both utility growth and of meeting shareholder obligations. For example, many utilities, as a natural extension of their historical role (electricity production and distribution), are forming subsidiaries which design and construct plants for non-utility developers, provide operation and maintenance services, or both. In some cases, the utility subsidiary may even obtain an equity position in the project. Another technique is to merge with other private utilities. The Pacificorp and Utah Power and Light merger is a good example of this and will be covered in more detail later in this chapter. The sum result of these factors is that today electric utilities build few new power plants, preferring instead to buy either power or other utilities to meet increased electrical demand.

\section{California}

California has many unique geographic features. Among them are two areas with well defined geothermal resources and several others with high geothermal potential. The Geysers geothermal field in northem California, and the Imperial Valley in southem Califomia were discovered, and in the case of the former, under development, long before the current energy environment evolved. The first attempt to harness geothermal energy for electrical generation was at The Geysers in 1922. In 1955, Magma Power Company discovered commercially usable amounts of dry steam, and in 1960, Pacific Gas and Electric Company built the first generating plant with a capacity of $11 \mathrm{MW}$. This plant and all subsequent ones at The Geysers use the natural steam directly, with no need to employ either flash or binary technology.

During the period 1950-1980, population growth in California resulted in a perennial growth in demand for electricity supplies. Geothermal generating units simply became part of the mix of plants which Pacific Gas and Electric Company built to meet growing demand in its service area. As seen in Table 1 , in 1980 most of Califomia's power came from oil-fired generator facilities, and was therefore subject to the dramatic rises in world oil prices. By 1983, Pacific Gas and Electric Company had built 16 geothermal power plants, all at The Geysers. The resource developer (i.e., steam supplier) was a consortium of Magma Power, Thermal Power, and UNOCAL. In 1980, nearly all the power listed in the "other" category (i.e., nontraditional hydro or thermal) for California was, in fact, geothermal energy (Table 1). 
Between 1980 and 1983, one private and four publicly owned geothermal plants were built at The Geysers. The private plant owner (formerly Occidental Geothermal, now Santa Fe) negotiated an avoided cost contract with Pacific Gas and Electric Company under the provisions of PURPA. The public agencies, on the other hand, were building plants to meet their own needs, literally avoiding the cost of purchasing power from investor-owned utilities; or thirdparty developers.

The first generation of geothermal plants in California outside The Geysers were Brawley (10 MW), Salton Sea (10 MW), and McCabe Unit \#1 (9 MW), all in the Imperial Valley. The Salton Sea plant is a flash plant, while the McCabe unit is a binary plant. Subsequent plants outside The Geysers include the $7 \mathrm{MW}$ Mammoth-Pacific plant at Casa Diablo and the $0.6 \mathrm{MW}$ Wineagle project at Wendel. These plants use small, modular, binary technology. Total net capacity for these plants is about ca $25 \mathrm{MW}$. The Brawley plant has subsequently been shut down and removed as it was an experimental facility that served its purpose; all the others are still operating.

In 1982, the California Public Utility Commission (CPUC) forecasted a shortage of power in the state, and ordered Califomia utilities to file short-run standard offers for power. The standard offers were essentially complete contracts, with set prices. These offers were to all qualifying cogeneration and small power production facilities without exception or conditions. In September 1983, the CPUC adopted Interim Standard Offer Number 4 (SO-4), which was based on utility long-nun avoided costs. The SO-4 contract provided both an economic and regulatory vehicle for the rapid development of independent power. The advent of Standard Offers greatly accelerated the viability, development, and recognition of the geothermal power industry.

The economic aspect of SO -4 is reflected in the name: standard terms and prices for energy purchased from nonutility producers. The firm power purchase agreement assured developers of long-term revenue streams which in turn allowed them to attract equity and debt financing.

The regulatory concept of the Standard Offers is also seen in the name: standard contract provisions preapproved by the utility commission. The cost of negotiating individual contracts with utilities was therefore significantly reduced. Similarly, utilities developed standard requirements for plant designs and interconnects with the utilities' transmission system, or thus energy system compatibility.
Under terms of the standard offer contracts, Pacific Gas and Electric and Southern California Edison (SCE), the two largest private utilities in Califormia, agreed to purchase over $18,000 \mathrm{MW}$ of new capacity from independent power producers. By late 1984, utilities became alamed that commitments to buy power would displace nuclear, fossil, and even geothermal, and economic hydropower from the Pacific Northwest. This was clearly not the intended result. The California Public Utilities Commission responded in July 1985 by suspending the issuance of SO-4 contracts, and avoided costs fell dramatically in response to the perceived surplus. By 1987, avoided costs were one-fourth 1982 levels. The CPUC has since issued a revised long-run standard offer that includes a total capacity limitation and a competitive bidding scheme to determine the actual price to be paid to qualifying facilities.

As of December 31, 1988, geothermal power from independent energy producers accounted for $571 \mathrm{MW}$ online, and a total of $886 \mathrm{MW}$ contracted capacity in the state. Hence, new projects in California continue to be built under prior Interim Standard Offer Number 4 contracts. Of the remaining outstanding contracts, several will expire in 1989. The final SO-4 contract offer will not, however, expire until June 1990. A near term surplus of electrical capacity is now forecast in California, and it is anticipated that this will significantly slow near term geothermal growth. The total of utility and non-utility geothermal capacity on-line in California as of May 1989 is 2,344 MW.

The second generation of geothermal power plants in California outside The Geysers use new, smaller, and often modular technology. These plants include the Coso Hot Springs project (75 MW), ORMESA \#1 and \#2 (39 MW), and Vulcan (34 MW). Both binary and double flash technology are used in these newly commercial plants. All of these projects have been built since 1986 and account for $148 \mathrm{MW}$ of net capacity. These commercial plants all have standard offer contracts to secure their market for power.

Projects now being constructed or which have recently come on-line include the Aidlin; Amadee; Bear Canyon; Coso Navy 2, and BLM East and West; Del Ranch; GEO East Mesa; Elmore; Leathers; Salton Sea 3; and West Ford Flat plants. These projects are on-line or scheduled to be in operation by mid-1990, and will add $403 \mathrm{MW}$ of net capacity. All plants have standard offer contracts to sell power at various prices, typically about 6.0 to $8.3 \mathrm{kWh}$ for energy, plus capacity payments and escalation clauses. Some contracts, however, provide for higher rates during peak periods. 
Each California utility has responded to changing energy market conditions in its own way. Southern California Edison (SCE), which now serves nearly all the southern part of the state, led that evolution. SCE aggressively bought power from independents and formed subsidiaries to participate in non-utility development. SCE has contracts for $743 \mathrm{MW}$ of geothermal power, of which $441 \mathrm{MW}$ are operating. Power is being purchased from locations as far away as northern Nevada. In addition, SCE created two subsidiaries to participate in geothermal development: Crescent Valley Energy and Mission Power Engineering Company. Crescent Valley Energy engineered and is an equity partner in the $15 \mathrm{MW}$ Beowawe project in Nevada. Mission Power Engineering is the SCE subsidiary which contracts to do engineering work for independent energy producers. Mission is active in all California geothermal areas. The company is both building and contributing equily to the Aidlin $20 \mathrm{MW}$ project in The Geysers; and has an equity position in the GEO East Mesa project. Mission built two $27 \mathrm{MW}$ geothermal power plants at Coso Hot Springs under a $\mathbf{\$ 7 0}$ million turnkey contract. Mission continues to perform turnkey engineering and construction work on the various Coso projects. Mission also participated in and built two $34 \mathrm{MW}$ (net) geothermal power plants at Niland in the Imperial Valley under a $\$ 132$ million financing arrangement. Future geothermal projects involving Mission Power are very likely.

\section{Nevada}

Geothermal resources in Nevada have been known for many years due to the presence of numerous surface manifestations and active exploration in the state. Most sites have liquid dominated resources under $300^{\circ} \mathrm{F}$. However, some sites, e.g., Beowawe, had identified temperatures in excess of $400^{\circ} \mathrm{F}$ as early as 1965 . These geothermal resources could not, however, be economically used to generate electricity until the 1980 's due to resource characteristics, available technology, and low energy prices. It wasn't until the early to mid 1980s that advances in double flash and binary conversion technology made generation from low temperature resources technically feasible and economically viable in Nevada markets.

Flash technology was developed primarily in New Zealand and Japan. Flash technology was first tested in the U.S. in California, then applied commercially in Nevada at the Beowawe double flash plant in 1985. Binary technology, using a secondary working fluid, was applied to low temperature $\left(<120^{\circ} \mathrm{C}\right.$ [ $\left.\left.<50^{\circ} \mathrm{F}\right]\right)$ Nevada resources in 1984 , a first in the U.S. for such low temperature generation.

Most of the known geothermal resources in Nevada occur in the northem part of the state, an area served by Sierra Pacific Power Company (Sierra). Sierra's total service is about $\mathbf{8 0 0}$ average $\mathrm{MW}$. Therefore, Nevada geothermal developers first began negotiating with Sierra to either purchase electricity or wheel it to another utility. Sierra's position was that any new power should be self-generated, not purchased. Developers active in Nevada at the time included Phillips Petroleum, Chevron Resources, and a number of smaller independents. Phillips Petroleum was subsequently bought by Chevron resources. Independents include Caithness Resources, Geothermal Development Associates, Ormat, Oxbow Geothermal, Tad's Enterprises, and Yankee Power Company.

Three geothermal developers negotiated contracts with Sierra in the fall of 1983. The advent of binary technology in small package units was a driving force in these negotiations. Another factor was one company's decision to build a flash plant. Nevada's first operating geothermal power plant at Wabuska uses $105^{\circ} \mathrm{C}\left(220^{\circ} \mathrm{F}\right)$ water in a binary cycle plant to generate $600 \mathrm{~kW}$ of electricity. That plant came on line in 1984, and was the first successful use of such low temperature geothermal water to produce electricity commercially using binary technology. Sierra Pacific reportedly pays 5.1\& per $k W h$ for the energy. The Wabuska developers later doubled their capacity with the addition of a second unit. The other two pilot projects, Desert Peak and Steamboat Springs, began operation in 1985. Under contracts entered into, prices paid for energy vary between 6 and 7 cents per $k W h$.

The timing of pilot projects coincided well with actions taken by the Public Service Commission of Nevada (PSCN). In 1984, the PSCN enacted General Order 32 to help utilities determine avoided costs. Table 1 shows Nevada's heavy dependence on fossil fuel power (chiefly coal) as of 1980 . The power source proposed by Sierra to meet future needs was another coal plant. Yet in arguing before the PSCN, Sierra cited the availability of inexpensive Northwest hydropower as the basis for calculating avoided cost. The Nevada Geothermal Industry Committee lobbied for an equitable and simple avoided cost methodology. Action by the PSCN in 1985 and 1986 further clarified steps Sierra should take to accurately calculate their avoided costs, using coal-fired generation as the resource to be avoided.

In 1986, Sierra was directed by the PSCN to pay established avoided capacity and energy costs to QFs 
producing electricity that contribute to the first $35 \mathrm{MW}$ of incremental capacity by June 30,1987 . The result was that avoided costs were clearly established. Developers were no longer required to negotiate individual contract prices with Sierra. In addition, the amount of power needed by Sierra each year is now also predetermined. The PSCN approved additional blocks of capacity for Sierra beyond the June 1987 deadline after acting upon Sierra's resource plan.

Developers in Nevada responded with projects coming on-line in each of the last five years, 1984 through 1988. The first generation of plants in Nevada were the Beowawe and Wabuska units. The Wabuska $600 \mathrm{~kW}$ unit uses modular binary technology and came on line in 1984. The Beowawe $15 \mathrm{MW}$ unit uses double flash technology and came on line in 1985 . Total net capacity for the plants is about $16 \mathrm{MW}$. A power sales contract was negotiated at the Wabuska unit. The Beowawe plant accepted a standard contract offer from a California utility. Sierra wheels Beowawe power and purchases any excess at current avoided costs.

Other geothermal plants in Nevada include the Dixie Valley, Empire, Steamboat Springs, Soda Lake, and Yankee/Caithness projects. These projects, all built since 1986, account for ca $74 \mathrm{MW}$ of net capacity. Two of the largest projects, Beowawe and Oxbow, were built to sell power to a California utility (SCE). The Oxbow Geothermal plant, in an extraordinary move, built a 228 mile, $230 \mathrm{kv}$ transmission line to sell $50 \mathrm{MW}$ of power to SCE. Capacity exists on the line for up to $250 \mathrm{MW}$. Both the power line and plant were constructed in under 24 months. It is estimated that the transmission system cost between \$22-26 million. This reportedly represents about 20 percent of the total project cost. Considering the disproportionate length of the line, this cost is extraordinarily low and competitive with transmission costs associated with other generating projects.

Utah

Utah geothermal resources were not developed as sources of electricity until the early 1980s, for reasons similar to those in Nevada, but primarily the inability to negotiate a power purchase agreement. Developers active in Utah included AMAX Minerals, Phillips Petroleum, Union Oil, and one independent company, Mother Earth Industries. Only Phillips' successor in interest, Chevron Resources, and Mother Earth Industries remain active today.

All the known geothermal resources in Utah occur in territory served by Utah Power and Light Company (UP\&L). UP\&L is now a subsidiary of Pacificorp, also the corporate parent of Pacific Power and Light. UP\&L is, however, operated as a separate division. The Utah electricity market is dominated by UP\&L. Some municipal utilities and rural electric cooperatives buy power from the Westem Area Power Administration (WAPA), but most still have to use UP\&L lines to receive power.

Phillips Petroleum had made a significant discovery at Roosevelt Hot Springs in the mid 1970s. Yet Phillips was unable to come to terms with UP\&L for the purchase of steam. In 1980, Phillips Petroleum was finally able to negotiate a contract with UP\&L in a fashion based on The Geysers experience. Phillips negotiated an agreement whereby it would supply steam to a power plant to be built and operated by UP\&L. The Blundell geothermal plant began operating in 1984, and contributes $20 \mathrm{MW}$ of power to UP\&L's grid. Steam supplier and plant owner/operator are separated in ownership at the wellhead. In operation, Chevron Resources, which now owns and operates the Roosevelt field, is responsible for everything up to the power plant fence. Chevron has been unable to negotiate further steam contracts with UP\&L and it appears that Chevron Resources has done little to negotiate with other utilities.

Mother Earth Industries (MEI), on the other hand, "broke the ice" in negotiating the first power purchase agreements for geothermal generated electricity in Utah. MEI discovered a resource in 1980 at Cove Fort in southern Utah. When MEI initiated discussions with UP\&L, the published avoided cost was about 2 cents per $\mathrm{kWh}$. Retail rates, in contrast, were significantly higher. The company, with other independent power producers, participated in Utah Public Service Commission avoided cost proceedings. The result of the Commission's findings was to increase UP\&L's avoided costs to 5.4 cents per $\mathrm{kWh}$. MEI, however, chose to negotiate further with one of the municipal power purchasers--the City of Provo.

The City of Provo somewhat uniquely chose early on to lessen its dependence on power from UP\&L. In 1960, Provo had a load of about $10 \mathrm{MW}$, and was paying UP\&L 1.0 to 1.2 cents per $\mathrm{kWh}$ for power. At that time, Provo made a deal with WAPA to buy $50 \mathrm{MW}$ of power at about 1.5 cents per $\mathrm{kWh}$, an extraordinary move for the time. While most may have questioned the City's logic, it proved fortuitous: today, Provo's base load is $60 \mathrm{MW}$ and their average price is 4.5 cents per $\mathrm{kWh}$. In contrast, UP\&L's average price for power is around 7.8 cents per $\mathrm{kWh}$. Table 1 indicates Utah's extreme dependence on coal-fired electricity.

The City of Provo and MEI worked out an arrangement whereby $3 \mathrm{MW}$ of power is purchased by the city for about 
6.3 cents per $\mathrm{kWh}$ (energy and capacity), with a price drop after seven years. MEI built the $2.2 \mathrm{MW}$ Cove Fort plant in 1985, and added 1.7 MW of capacity in 1988. Provo has an option to purchase additional power at an undisclosed price. The City of Provo invested about a million dollars in the substation and power line required to connect to UP\&L's main transmission line. The City of Provo operates the plant, which is owned by MEI. MEI pays UP\&L/PP\&L a wheeling fee that started at about five-tenths of a cent ( 5 mills) per $\mathrm{kWh}$, but was reduced by the utility commission to threetenths of a cent ( 3 mills) in 1987.

Reservoir estimates indicate that additional power could be generated from the resources at both Cove Fort and Roosevelt Hot Springs. As a result, MEI is seeking letters of intent from other municipal utilities wishing to obtain nonUP\&L power.

\section{Oregon}

Geothermal resources in Oregon (and other northwest states) are well defined in the low temperature range under $100^{\circ} \mathrm{C}\left(212^{\circ} \mathrm{F}\right)$. Resources capable of generating electricity have, however, not been confirmed, but are likely to be found in both the Basin Range, and Cascades provinces. For a full analysis of geothermal resources in the Northwest, see Bloomquist, et al., 1985.

Developer interest in Northwest geothermal resources is reflected by federal leasing statistics. Table 2 shows end of year figures for federal leases in Oregon and Washington. As shown, federal lands leased for geothermal resources rose in the early part of the decade and have now declined to earlier levels. The reasons for this trend are unclear but increases track the projected need for power. Declines follow by as the surplus was announced. Maintaining a lease position is increasingly expensive and must be justified by electric market conditions.

Most leaseholders fall into the category of either resource development company, e.g., UNOCAL, or individual speculators. However, some Northwest utilities have geothermal leases. Both Portland General Electric (PGE) and Eugene Water and Electric Board (EWEB) have leases on Forest Service lands in the Oregon Cascades. EWEB drilled six shallow holes on their leases in 1979. All the wells were under $2,000 \mathrm{ft}$. $(610 \mathrm{~m})$ and results were encouraging but inconclusive. PGE has done no drilling to date, but is working on a development program with participation from Califomia Energy Company, another major lease holder.
Table 2

Federal Leases In Effect (Acreage)

$\begin{array}{lccc}\text { Year } & \text { Oregon } & \text { Washington } & \text { Total } \\ 1981 & 397,400 & 10,318 & 407,718 \\ 1982 & 449,315 & 62,503 & 511,818 \\ 1983 & 652,191 & 52,866 & 705,057 \\ 1984 & 641,499 & 36,593 & 678,092 \\ 1985 & 560,735 & 53,645 & 614,380 \\ 1986 & 526,827 & 73,263 & 600,090 \\ 1987 & 466,631 & 46,014 & 512,645 \\ 1988 & 419,546 & 0 & 419,546 \\ 3 / 31 / 1989 & 319,842 & 0 & 319,842\end{array}$

Source: BLM Oregon State Office Monthly Geothermal Fact Sheets.

Geothermal development companies active in Oregon include Anadarko Production Company, California Energy Company, Chevron Resources, Geothermal Resources International, Oxbow Geothermal, and UNOCAL. Numerous exploratory wells up to $2,470 \mathrm{~m}(8,100 \mathrm{ft}$ ) in depth have been drilled by these and other firms. Locations of past exploratory wells are concentrated in the Cascade mountains, Newberry Volcano, and in the lower Alvord Valley of southeastem Oregon. Current exploration efforts are on the Winema National Forest in Klamath County, where two temperature gradient holes are suspended and awaiting completion. A proposed production test well may be drilled in the near future at the lower Alvord Valley site.

The near term outlook for geothermal exploration and development is for generally slow activity due to low avoided costs and low utility interest due to the perceived power surplus. But companies with an eye to the long term market will be active. Competing sources of electricity include Canadian hydroelectric power and coal plants in the Northwest, Rocky Mountains, or northern Nevada regions.

As stated in the beginning of this chapter, large hydroelectric projects were built decades ago in the Northwest, with resulting electricity being less expensive than in any other region of the country. Not only is electricity inexpensive in Oregon, most utilities have long term projected electricity surpluses (mid 1990s to early 2000). In addition, wholesale power is available for purchase through the Bonneville Power Administration for less than $\$ .03$ per $\mathbf{k W h}$. Utilities are currently unwilling to purchase more expensive power from independent power producers or become involved in risky new power plant development projects. Low local power prices have therefore discouraged 
the development of new sources of electricity and have, in fact, contributed to an almost total lack of long term planning and a willingness to become involved in research, development, or demonstration initiatives by the states' utilities. However, this was not always the situation.

In 1981, the Oregon Public Utility Commission (OPUC) set out general policies and proposed rules for cogeneration and small power production contracting in response to PURPA. In December 1981, the four regulated utilities in Oregon submitted their first avoided cost schedules. During a short period in 1982-1984, utility avoided costs in Oregon and other northwest states were sufficiently high (over $5 c$ per $\mathrm{kWh}$ ) to encourage new power production. As a result, a small number of developers, frequently lumber mill owners with excess residues, negotiated power purchase contracts in Oregon.

The result was the signing of 46 contracts for projects larger than $100 \mathrm{~kW}$ with Oregon investor-owned utilities. If all of these projects had come on-line, total power production would be $387 \mathrm{MW}$. However, some of the projects have failed to come on-line in intervening years. Inability on the part of the developer to secure necessary permits or financing is the chief reason. It is estimated that as of January 1, 1989, a total of $158 \mathrm{MW}$ of wood-fired cogeneration, small hydro power, MSW-to-energy, and even one small wind farm were operating. No new contracts have been signed since 1985, when avoided costs dropped steeply from about 6 cents per $\mathrm{kWh}$ to 3 cents.

No commercial geothermal power sales contracts were signed. However, one research and development contract was signed in 1984. Wood and Associates negotiated an agreement with Pacific Power and Light to sell $1 \mathrm{MW}$ of geothermal power for one year. The site was in Lakeview and the plant was to use low temperature water in a binary system to generate electricity. In return for the price for power, $\$ .07$ per $\mathrm{kWh}$, the seller was to collect and provide Pacific with research data on plant operation. The contract was to be in force for a period of one year from the date of full operation. However, the plant never operated beyond multi-day trials, and is now shut down.

The Lakeview binary project produced some results in spite of brief operation. The need for long term reservoir production testing was demonstrated. The volumes of hot water necessary to run the plant were large, over 113.56 liters per second $(1,800 \mathrm{gpm})$ from two wells in the original design. However, only one well was drilled, and pump tested at about 44.162 liters per second (700 gpm). Effects were noticeable in nearby wells from the short ( 2 day) pump test.
A longer term test was never performed, and would have been required to detemine reservoir characteristics. No mitigation was offered to affected well owners, nor was an injection well drilled. Both actions most likely would have been requisites to full production and subsequent development.

The Lakeview binary plant also demonstrated the value of a power sales agreement with prices capable of supporting project investment. Long term, adequate pricing is needed to make geothermal projects viable. For example, a 10 year term, 6 cent per $\mathrm{kWh}$ (energy or capacity) price is much more attractive compared to a 1 year, 7 œnt per $k W h$ (energy only) price agreement.

The Lakeview project therefore proved up two considerations that project financiers focus on: proven reservoir deliverability and attractive power sales agreements. Techniques to confirm these project parameters are discussed in Chapter 3.

The considerable leeway given states by the FERC PURPA 210 rules has been critical to Oregon's implementation of PURPA. This flexibility has increasingly been used by the OPUC. The initial policy decisions were based on the need for new resources. The most notable decisions which encourage resource development occurred in 1981, 1982, and 1984. When demand forecasts switched from deficit to surplus, OPUC policies made a dramatic shift. Subsequent OPUC decisions in 1985, 1986, and 1987 changed some policies which modulate the $Q F$ development marketplace beyond the signals provided by falling avoided costs. For a full discussion of this subject, see Bain, 1989.

The evolution of avoided costs in Oregon has followed two distinct tracks, depending on whether they are state regulated or not. Oregon is served by 3 private or investorowned utilities, 6 public utility district, 11 municipallyowned utilities, and 17 cooperatives. The three latter groups are not regulated by the OPUC and are generally lumped into the category of consumer-owned utilities or COUs. Some of the COUs own their own generation, but most provide only distribution of power purchased from BPA. The consumer-owned utilities base their offers to QFs on BPA wholesale rates and thus have had very low avoided costs compared to the regulated IOUs. The IOUs have, at one time or another, paid several times the COUs' rates or slightly less, depending on the IOUs' need for capacity. Consequently, very little $Q F$ resource development has occurred in COU territories. Most of Oregon's QFs were motivated by the favorable avoided costs available from the IOUs in the early 1980s. Once the capacity surplus was 
established, IOUs' rates fell so dramatically that no new contracts have been signed since 1985.

The level of IOUs' experience with QFs and sophistication in avoided cost methodology has increased greatly since PURPA was first implemented in Oregon in 1981. Unfortunately, this is not the case with the majority of Oregon's COUs. It is unknown how well the many state policies that were formulated during the surplus will serve when resources are once again needed. The administration of PURPA in Oregon was recently studied by a joint public/private group. It recommended refinements to the OPUC encompassing all that has been leamed to date. In addition to recommended OPUC changes, further large market place changes are expected over the next few years.

A large change is occurring in the entire Pacific Northwest, resulting from the merger of Pacificorp and Utah Power and Light. In October 1988, Pacificorp, parent of Pacific Power and Light (PP\&L) completed the purchase of Utah Power and Light (UP\&L). PP\&L and UP\&L will now operate as separate divisions of Pacificorp. The significant results of this merger are several: first, the new company is now the fifth largest investor-owned utility in the nation. Second, the resulting utility can now transmit Northwest electricity to the Southwest via both the Pacific Intertie and UP\&L lines. Third, and perhaps most important, is the new generation facilities which Pacificorp acquired and the complementary load profiles of the two new divisions.

PP\&L can now draw upon UP\&L coal plants to meet winter peak loads. Similarly, UP\&L can use PP\&L's hydro and coal facilities to meet summer peak demands. The net result is an efficient use of the two systems' power plants and transmission facilities. This increase in plant and power line efficiency allows PP\&L (and UP\&L) to defer new plant construction farther into the future than previously anticipated by either.

\section{Washington}

In Washington State, QF development has been sporadic due to relatively low avoided costs and the need to individually negotiate the terms and conditions of each purchase. The low avoided costs stems largely from the power surplus affecting the region in recent years. The existence of abundant and relatively low-priced purchase opportunities bas pushed the anticipated need for new thermal resources out into the future; the correspondingly lower avoided cost price signals have generally not been high enough to stimulate large amounts of QF development.
Washington State is served by three private or investorowned utilities, 21 public utility districts, 16 cooperatives, and 20 municipally-owned utilities. Some of the public utilities own their own generation while most provide only distribution and billing services and are "full-requirements" customers of the BPA. While the public utilities are expected to remain in a surplus condition until (or even past) the tum of the century, the IOUs are rapidly approaching a generating resource deficit. Puget Power has, in fact, actively sought new capacity. Even Tacoma City Light, one of the publics, is seeking new capacity. With this multitude of utilities, utility boundaries and overlapping service territories, diversity of need, and variation in avoided cost offers, wheeling access and wheeling charges are critical issues for Washington's independent power developers.

Avoided costs for Washington's utilities were very attractive in the early 1980s as an energy deficit was predicted. A hydropower licensing "gold rush" ensued with permits filed on over 450 potential sites. Geothermal developers held over 50,000 acres of potentially valuable geothermal leases. The energy shortfall, however, was rapidly transformed into a 2,000 average megawatt surplus after BPA and the Power Council completed load forecasts in 1982 using refined econometric techniques to replace the then current practice of using "sum-of-the-utilities" straight line extrapolations. As a consequence, avoided costs tumbled and interest by independent power producers evaporated. As can be seen in Table 2, no geothermal leases are at present being held in Washington.

In the state of Washington, 20 small-scale bydroelectric projects with a combined generating capacity of $77 \mathrm{MW} ; 3$ solid waste-to-energy facilities with $55 \mathrm{MW}$ of electrical output, 4 cogeneration projects with $34.5 \mathrm{MW}$ of generating capability, and 4 wastewater treatment facility digester gasto-energy projects with $5 \mathrm{MW}$ of electrical production have come on-line (or are in the final stages of construction) since the passage of PURPA. These numbers, however, represent only a small portion of Washington's untapped and undentilized cogeneration and renewable resource generating potential.

In retrospect, PURPA worked well in Washington. During periods of forecasted generating resource need, avoided costs were high and served as an incentive to $Q F$ development. Two hydropower projects signed power purchase agreements with Puget Power for a levelized price (over 35 years) of $7.5 \% / \mathrm{kWh}$. Avoided costs declined when Washington utility cost models accounted for price-induced decreases in forecasted load growth. The need for new 
thermal resource development was therefore deferred. Puget's current levelized avoided cost is about $4.9 \mathrm{~d} / \mathrm{kWh}$ (over a 20 year period). This properly functioning avoided cost methodology serves to establish an appropriate, effective, and reactive price signal to resource developers.

In Washington State, "standard prices" or power purchase offers were not made. Instead, a variety of power purchase contracts were negotiated by developers of qualifying facilities with investor-owned utilities, public utility districts, and municipally-owned and operated utilities. Power purchase rates were negotiated and vary according to firm energy production, seasonality of output, project ramping rate, and load following capability; performance guarantees, ability to schedule maintenance or downtime, rights of refusal, power plant purchase options, project start date, and length of contract; front-loading or levelization provisions; and the ability of the project to provide "demonstrated" capacity.

Legislation was also enacted which allows PURPA to work effectively. Initially laws established ownership rights and provided irrigation districts, PUDs, and municipalities with expanded enabling powers. Financial incentives for renewable resource and cogeneration projects were also created. Permitting processes were streamlined and, in some cases, simplified. In addition, laws were passed which are designed to ensure that development proceeds in an environmentally acceptable manner.

Finally, recent activities in both the electric and natural gas industries and regulatory change, at both the national and state level, will affect the future rates of development for both cogeneration and renewable resource projects. In particular, utility least-cost planning requirements, the imposition of competitive bidding resource acquisition schemes, and natural gas availability and pricing will impact both utility avoided cost projections and the rate of $Q F$ development. 


\section{Chapter 2}

\section{Design Innovations for Efficiency and Reliability}

\section{Introduction}

Geothermal power generation in the United States has undergone an innovative revolution since the early 1980 s. From the early 1960s until the late 1970s, the American geothermal industry was, for all practical purposes, a single technology unique to The Geysers. The resource was dry steam at a fairly constant temperature and pressure with low amounts of noncondensible gases. Resource companies led exploration for and development of The Geysers steam field; Pacific Gas and Electric Company (PG\&E) was the only utility involved in design, construction, and operation of geothermal power generation facilities. Steam was purchased from the resource companies at a percentage of the selling price of the electricity. Condensate was used for cooling water with any excess sent back to the resource company for injection at an additional cost.

Since 1980, however, "The Geysers Scenario" has rapidly diversified. Steam discovered in recent years can contain noncondensible gas in excess of 5 percent. New resources being developed in other geographical areas of the western United States are typically hot water instead of steam, with temperatures varying from near boiling to $260^{\circ} \mathrm{C}$ $\left(500^{\circ} \mathrm{F}\right)$ or above. Water quality varies from several hundred PPM total dissolved solids to upwards of 350,000 PPM.

Resource companies are still in the business of exploring for and developing resources, but some are no longer satisfied merely to sell steam or brine. Several have begun to construct, own, and operate power generating facilities. This leaves the utility with the sole role of power marketer. However, not all utilities have accepted this role; cases now exist where resource exploration and development are jointly funded by utility subsidiaries in return for lower "fuel" prices. Where traditional resource company/utility company roles are maintained, the sale of the steam or brine is more likely to be based on pounds of steam or millions of Btu purchased. Furthermore, condensate or spent brine is no longer looked upon merely as a waste product with associated disposal costs, but, in many areas, as a vital commodity for prolonging the life of the reservoir, mitigating land subsidence, and even as a means of disposing of noncondensible gases.

Changes in the geothermal industry have been prompted in part by federal legislative initiatives such as the passage of the Public Utility Regulatory Policy Act of 1978 (PURPA) (P.L. 95-617), the Energy Tax Act of 1978 (P.L. 95-618), and the 1980 Windfall Profit Tax Act (P.L. 96223). PURPA requires that electrical utilities interconnect with qualifying facilities and purchase electricity at a rate based upon their full avoided cost (i.e., the cost to an electric utility of purchasing, financing, building, and operating an additional unit of electrical generating capacity or, if capacity expansions are not required, the incremental cost of operating the most expensive resource(s) in the utilities generating mix). Qualifying facilities (QFs) include geothermal and other generating technologies and cogeneration projects which satisfy maximum size, ownership, location and/or efficiency criteria. The Tax Acts allowed for the deduction of intangible drilling expenses and extended the percentage reservoir depletion allowance, traditionally available to oil and gas, to geothermal (depletion permits the owner of a production well to compute deductions on percentage of income produced rather than as a function of capital invested. In addition, investment tax credits of 25 percent and accelerated depreciation over five years for generation facilities were also provided by tax law.

Other contributing factors are increased competition with both conventional and renewable energy resources, greater environmental awareness and concerns, and the realization that hot water reservoirs are more abundant than dry stream fields. Hot water resources could provide several thousand megawatts of electrical generation. In fact, as much as 90 percent of the potentially recoverable hot water resources are below $177^{\circ} \mathrm{C}\left(350^{\circ} \mathrm{F}\right)$.

This chapter addresses past developments, current innovations in new plant development, and the increasing benefits of geothermal power. Emerging information from a diverse array of projects is presented. 


\section{Figure 1 \\ New Western States Goothermal Plants BPA Project Intervlows}
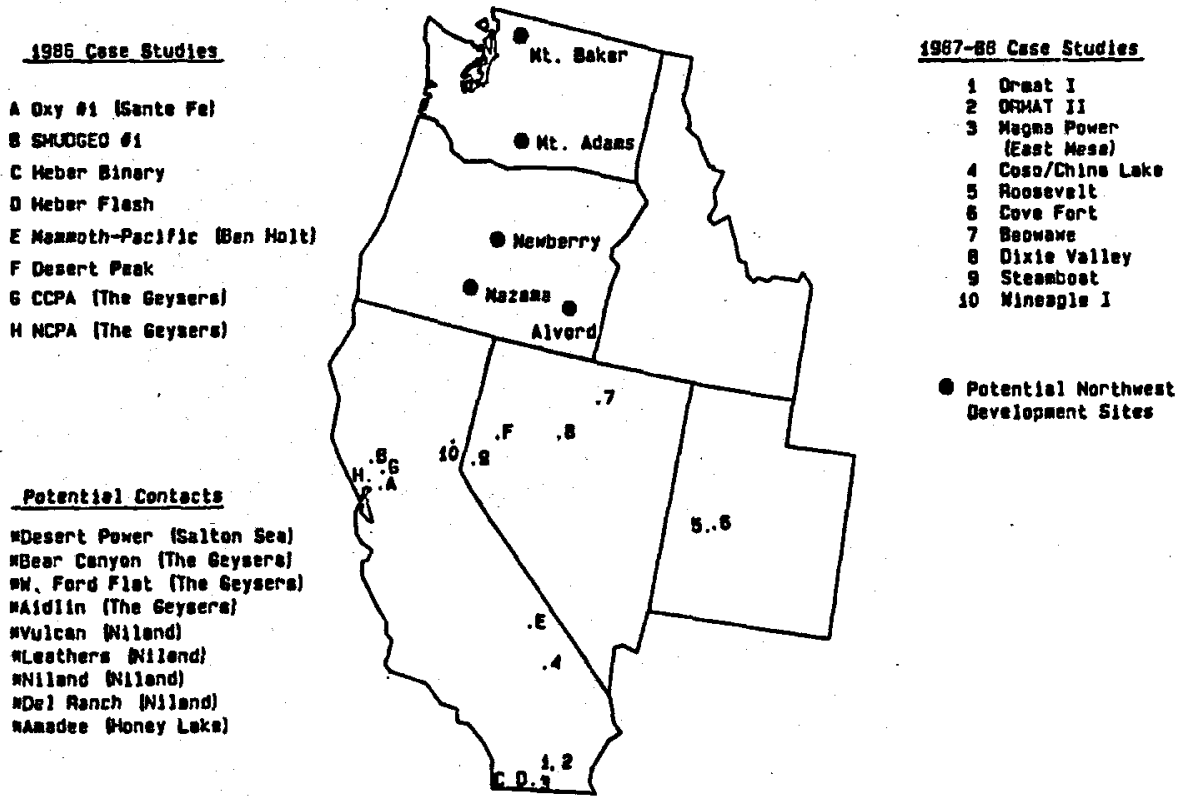

The following information is from developers who were willing to share data either publicly or in direct interviews. All facilities were visited. Each project emphasizes unique features or experiences (Figure 1).

Table 3 is a summary of the industry's accomplishments documented by this report.

\section{PURPA Influence on Contemporary Geothermal Plants \\ Plant Design}

Several recent geothermal power projects have departed significantly from The Geysers' precedent in ownership and operating structures. This illustrates that a two-panty structure is no longer essential. Of course, the twa-party arrangement still wotks; it's simply not the only means of structuring geothermal power generation development.

Title II of the Public Utility Regulatory Policies Act of 1978, provides the legal basis for a non-utility to construct and operate a power plant for the sole purpose of selling the electricity produced. Such a plant is termed a Qualifying Facility (QF). Such plants recover costs only through electrical production. PURPA requires the local utility to interconnect with the project and either purchase the power at the utility's avoided costs or wheel the power to another purchasing utility. "Avoided Cost" is defined as the

incremental cost to an electric utility of electric energy or capacity or both which, but for the purchase from the qualifying facility or qualifying facilities, the utility would generate itself or purchase from another source. To remain exempt from regulation as a utility, a QF can produce up to $80 \mathrm{MW}$ net output when using geothermal energy.

Therefore, the basic objective for plant design is net power production of $80 \mathrm{MW}$ with the highest achievable reliability while giving ample consideration to protection of stream reserves supplying the plant and project economics. Thus, for the prudent developer, maintaining power on-line maximizes revenues, regardless of plant size. Meeting performance and cost criteria is vital to a PURPA developer. The objective of producing power in order to be paid distinguishes PURPA developers from utilities who are guaranteed a fixed rate of retum based on capital investment, independent of plant performance.

Thus for the first time power plant design and construction is not the sole domain of utility engineers. Any independent developer can now hire a competent architectural and engineering firm with experience to design and construct a generation facility for operation by the independent power producer. In fact, some resource companies developed sufficient in-house expertise to design power plants, e.g., Phillips Petroleum (Dipple and Gonser, 1985). 
Table 3

Geothermal Plant Data Matrix

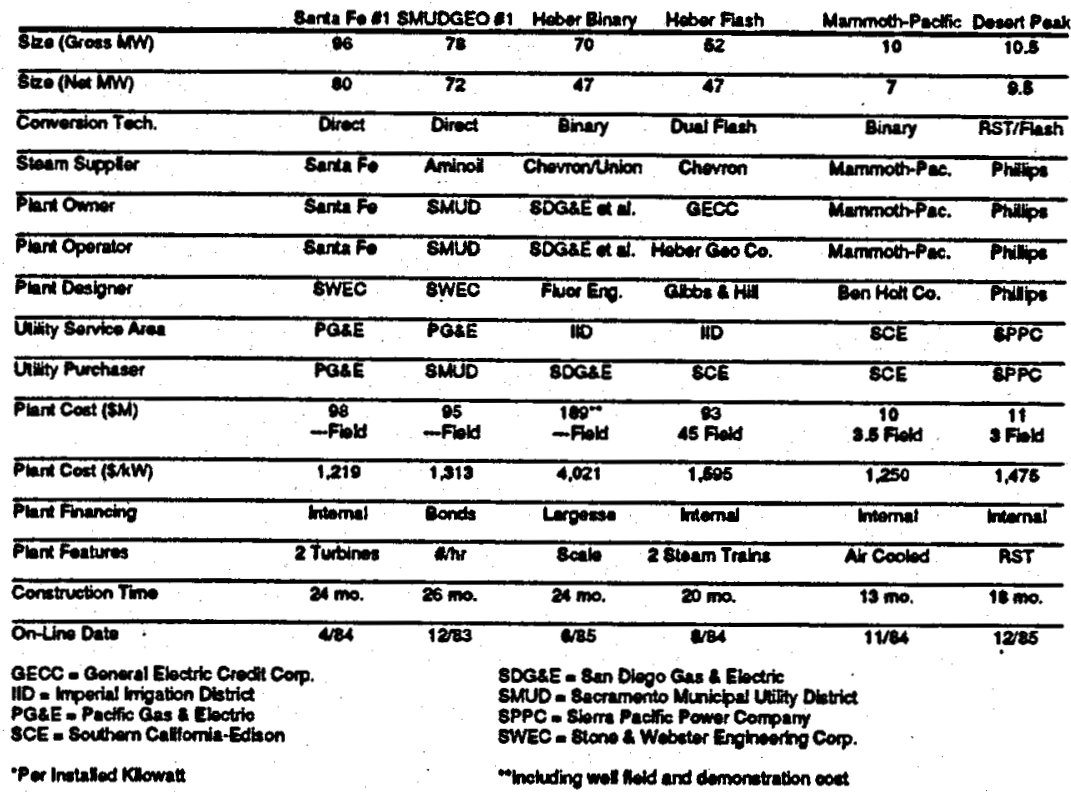

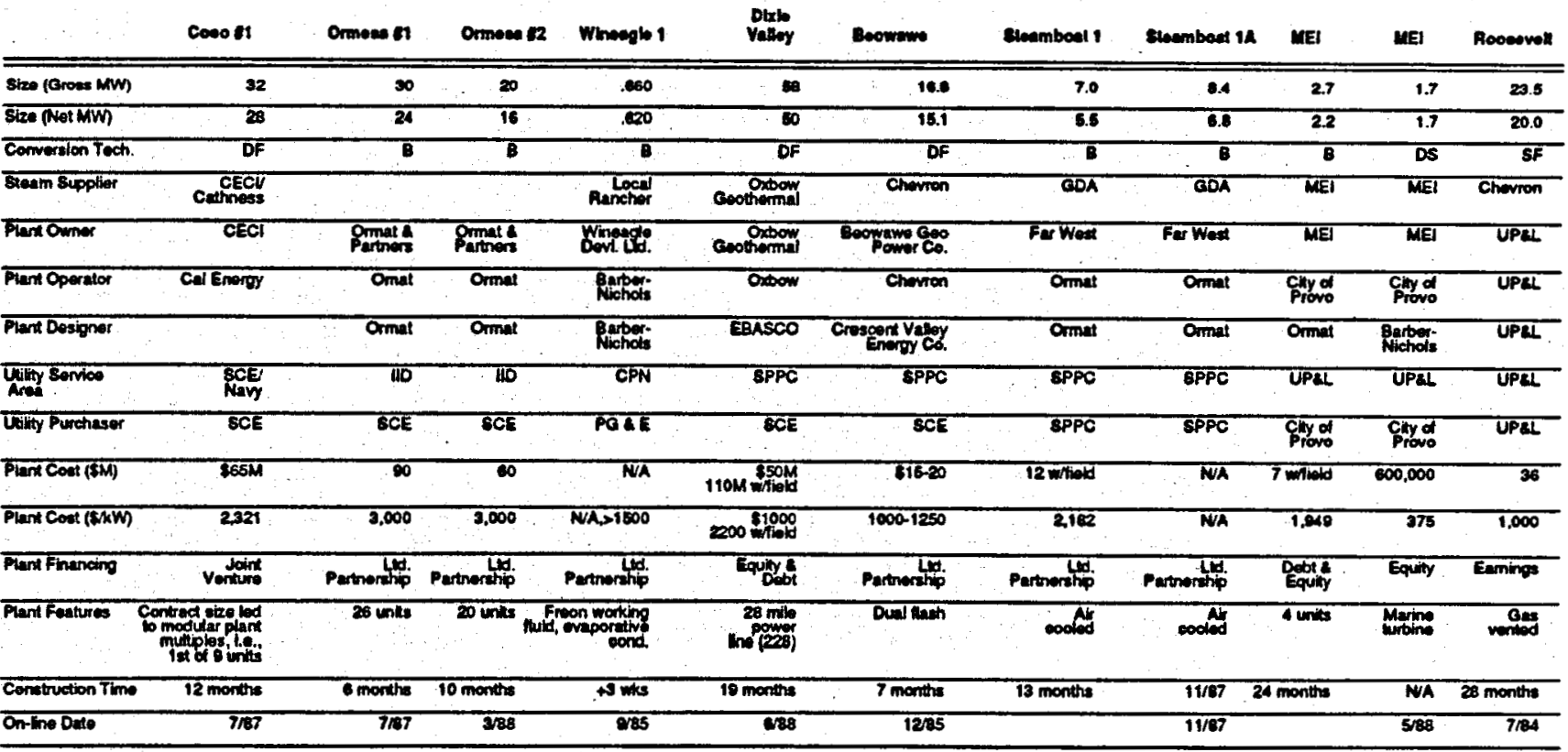


The Santa Fe \#1 geothermal plant at The Geysers typifies new PURPA project structures. Two widely used indices to measure the performance of electric utility generating plants are the availability and capacity factors. Availability refers to whether a plant was capable of generating electricity during a given period of time, regardless of whether it actually did so. The capacity factor is a measure of the power a plant actually produces compared to its potential output over a given period. The capacity factor is always equal to or less than the availability factor, because the utility typically does not require the entire rated output of any particular plant during the entire period considered. Capacity factor is normally based on the plant's gross generation, the entire amount of electricity produced by the generator(s). In this paper, a narrow definition of capacity factor, one based on net rather than gross power generation, is used. This $80 \mathrm{MW}$ (net) plant is owned and operated by Santa Fe Geothermal, Inc. The Santa Fe facility, previously owned by Occidental Geothermal, is a resource development company, not a utility. Yet they went beyond the historical role of drilling wells and supplying steam. Occidental Geothermal hired Stone \& Webster Engineering Corp. to design and supervise construction of an $80 \mathrm{MW}$ power plant with the highest achievable reliability (Fesmire, V.R., 1985). Occidental achieved its desired results using two turbines providing 100 percent redundancy, an unusual design. This unique design duplicates many active components in order to achieve maximum availability and capacity. Santa Fe now owns and operates both the wellfield and the power plant. Other independent power producers use different techniques but desire the same thing: to produce and sell as much power as is possible over the year.

In order to achieve the greatest possible cost effectiveness and maximize returns, non-utility design standards are becoming commonplace. The adequacy of such non-utility construction is being confirmed by the operating histories of plants throughout California, Nevada and Utah.

PURPA appears to be $\mathbf{a}$ force in changing the historical separation between, and motives of, "fuel" suppliers and plant developers. The interface between parties is shifting from the field/plant boundary to the transmission switchyard. This shift results in a sharing of the risk and reward of an integrated operation. Both resource development and power plant operation are optimized by the financing and scheduling flexibility of these new plants.

\section{Plant Development}

U.S. utilities traditionally designed, built, and operated generating plants while obtaining fuel supplies from resource developers. New power plants are often neither owned or operated by utilities. Thus, managing the risk of maintaining adequate energy supplies is a new role for the utility who no longer has full control over system supplies; and developers and third parties now find themselves generating electricity and marketing electricity as a product to meet utility needs. These and other points emerged during an Electric Power Research Institute (EPRI) meeting (EPRI AP-3686, 1984):

1. Investors find the shared risk approach of third-party financing of power plants more palatable;

2. PURPA, plus federal and state tax credits, make geothermal projects more attractive than before to third-party investors. This can be attributed to California's initiative in standard contracts which lead to more clearly defined levelized prices for power, enabling revenue streams to be easily forecast; and

3. Resource developers now find themselves marketing electricity as a wholesale product and brokering financial arrangements, as well as developing energy resources.

Resource companies have expanded their roles in order to package generating projects which meet their own objectives, are acceptable to utilities and regulators, and are compatible with the financial objectives of investors. In such arrangements, the utility may seek an option to purchase the generating plant at some time in the future, but this is not a universal provision.

Avoided costs vary from state to state. In areas that enjoy less expensive fossil fuels or hydro or nuclear power, low avoided costs do not encourage exploration or development; witness the lack of development in the Pacific Northwest of the United States. However, QF electricity can be "wheeled" to an area of higher avoided costs, which may provide a mechanism for development of prospects in low avoided cost areas. Nevada and the Imperial Valley of southem Califomia provide examples of such areas.

PURPA contracts for three generating facilities in Nevada were approved by the Nevada PUC in 1983. The small size of these first Nevada qualifying facilities (5-10 MW) did not justify the transmission line costs to move the electricity out of state. However, $17 \mathrm{MW}$ of power from Beowawe, Nevada, is being wheeled by Sierra Pacific to Southem Califomia Edison Co (Lunis, 1985). In another 
instance, an ambitious non-utility developer built a 228 mile power line from central Nevada to reach the markets of southem California (Oxbow, 1986; Benoit, 1987). In the Imperial Valley of southem Califomia, all new plants online since 1985 supply electricity to the greater Los Angeles area.

\section{Plant Operation}

Because geothermal wells run the risk of failing if frequently turned off or "shut in," geothermal resources tend to be developed to provide base load energy. Achieving high availability is a design, contractual, and operational consideration. Such energy production warrants a capacity payment, which is a monetary premium added to the price for the capability to deliver exergy. Naturally, some small amount (2\%) of down time for maintenance will be necessary; but designing to minimize operating outages (e.g., using parallel systems to permit operation during maintenance) should be given high priority.

As noted earlier, Occidental had Stone \& Webster Engineering Corp. design a plant which would provide the highest availability of maximum allowable generation under PURPA: $80 \mathrm{MW}$. In order to accomplish this, two redundant turbines were installed. After the first two years of operation, plant availability stood at 99.9 percent and the actual capacity factor achieved was 98.6 percent (Fesmire, 1985).

In addition to parallel or redundant components, other techniques used to achieve maximum capacity and availability include spare parts on site and partial shutdown capability. SMUDGEO \# 1, another Geysers plant, is owned and operated by the Sacramento Municipal Utility District. The SMUDGEO plant experienced a total of six outages during the first year of operation. Of these, two were scheduled outages and four were forced by the receiving utility (Kleinhans and Priedeaux, 1985). Yet the SMUDGEO plant, with only a single turbine train, had 98.46 percent availability and a 93.6 percent capacity factor for its first year of operation (Kleinhans \& Priedeaux, 1985). Plant operation therefore should strive to achieve the highest availability as a baseload plant, curtailed only if absolutely necessary. The incentive to do so goes beyond PURPA, to basic economics. Since plant costs are fixed, maximum operation yields maximum retums to the owner.

Such an operating philosophy can be characterized as "no production = no payments." This orientation is different than one in which the plant is paid for (i.e., rate-based) regardless of level of power produced. The objective of producing power in order to be paid distinguishes PURPA development from traditional utility operation.

\section{Increased Efficiency}

Introduction

Increased conversion efficiency in contemporary geothermal power plants has been largely encouraged by: (1) structural changes in contracts between resource suppliers and plant operators; (2) changes in well field and plant ownership arrangements, and (3) use of resources with increasingly lower enthalpy to generate electricity. The case studies that follow present efficiency aspects of the plants described.

\section{The Geysers Case Studies}

\section{SMUDGEO \#I}

At The Geysers, the SMUDGEO \#1 $72 \mathrm{MW}$ power plant (which went on-line in 1983) is an excellent study of increased conversion efficiency. SMUDGEO \#1 is owned and operated by the Sacramento Municipal Utility District and purchases steam from Geysers Geothermal on a perpound basis (Tucker and Kleinhans, 1980). Since the steam is paid for in this fashion rather than as a percentage of electricity sales, a tremendous incentive exists to generate as many kilowatts per pound of steam as is economically feasible.

In order to obtain maximum possible efficiency, SMUDGEO uses a highly efficient four-flow turbine with 63 $\mathrm{cm}$ (25 inch) last-stage blades (Figure 2). The $63 \mathrm{~cm}$ (25 inch) blade was the largest ever used at The Geysers. Efficiency is also increased through the use of an oversized heat rejection system. This consists of a 23,200 square meter (250,000 sq.ft.) titanium tubed, two-zone condenser and two six-cell, Class 600 wood cooling towers. The four-flow turbine with its $63 \mathrm{~cm}$ (25 inch) last-stage blades and the oversized beat rejection system allow the plant to operate at a back pressure of $3.8 \mathrm{~cm}$ (1.5 in.) $\mathrm{HgA}$. This requires 5.9 to 6.4 kilograms ( 13 to $14 \mathrm{lbs}$.) of steam to produce $1 \mathrm{kWh}$. In comparison, the Pacific Gas and Electric Company (PG\&E) $110 \mathrm{MW}$ Unit 16 which came on-line the same year as SMUDGEO \#1 has 17,000 square meter $(184,000$ sq.ft.) of condenser area and an 11 cell cooling tower (Stone and Webster Engineering Corporation, 1986). PG\&E Unit 16 consumes 8.2 to 8.6 kilograms ( 18 to $19 \mathrm{lbs}$.) of steam per tWh produced. SMUDGEO's efficiency is also increased through the use of an innovative three stage noncondensible gas removal system. The two first stages uses steam jets while the third is comprised of three 50 percent capacity liquid ring vacuum pumps. Again, in comparison, the PG\&E Unit 16 uses 880,000 kilograms/hour $(1,940,000 \mathrm{lbs} / \mathrm{hr}$.) to 
produce $110 \mathrm{MW}$, while the SMUDGEO \#1 plant utilizes only 431,000 kilograms/hour $(950,000 \mathrm{lb} / \mathrm{hr}$.) to produce 72 MW (Stone and Webster Engineering Corporation, 1985). Thus a desired 25 percent inprovement in conversion efficiency was achieved over previous typical steam consumption rates at The Geysers.

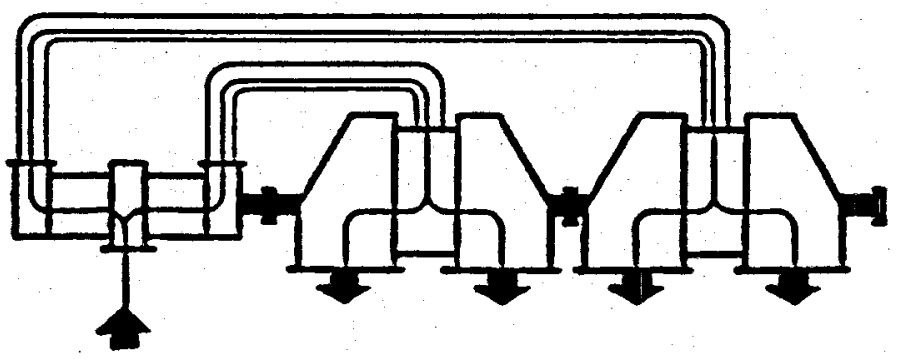

Figure 2

\section{Four-Casing Quadruple-Flow}

In order to achieve this, all major equipment for SMUDGEO \#1, including the hydrogen sulfide abatement system, was purchased utilizing a bid evaluation format which penalized offerings for inefficient use of steam and/or electricity at a capitalized rate of $\$ 313,400$ per 454 kilograms $(1,000 \mathrm{lbs}$.) of additional steam required and $\$ 6,500$ per additional kilowatt of parasitic load (Kleinhans and Prideau 1985).

\section{Santa Fe \#I}

The Santa Fe \#1 geothermal power plant, which is located less than a mile from SMUDGEO \#1, is another unique study. Santa Fe was the first company in The Geysers to control the operation of both the steam field and the power plant and sell power under a PURPA contract. Because Santa Fe is both steam supplier and plant operator, each pound of steam both produced from and remaining in the reservoir has a premium value, and, thus there is a strong incentive to use that steam as efficiently as possible.

Initial design studies completed for the Santa Fe facility by Stone and Webster Engineering Corporation indicated (as with the SMUDGEO \#1 plant) that highest efficiency could be obtained through the use of a four-flow turbine (Figure 2). However, due to Santa Fe's common ownership of the plant and well field, plus PURPA contract incentives, it was highly desirable to obtain both highest allowable capacity and availability for maximum revenue with minimum per unit production costs. It was therefore determined that instead of using a single four-flow turbine arrangement, which would have to necessarily operate at below maximum efficiency because of turbine fouling or experience regular shut downs for turbine blade refurbishing, that two two-flow turbines (Figure 3) would provide both higher capacity and availability with little or no loss in efficiency. Capacity and availability is assured because each of the two turbine generators can produce the $80 \mathrm{MW}$ allowed under PURPA by operating at increased pressure and with increased steam flow.

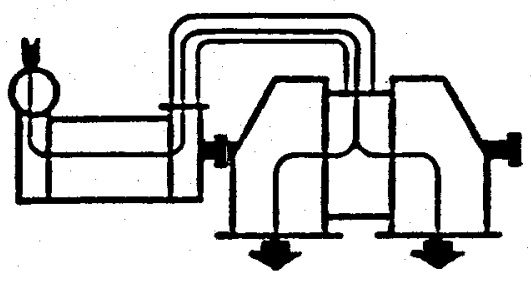

Figure 3

\section{Two-Casing Double-Flow}

The use of two turbine generators thus allows for more frequent refurbishing of the turbine blades to maintain performance at design value without significant loss of revenue and without the need to maintain two spare rotors.

Higher efficiency was also ensured through selection of a turbine design which incorporated partial arc admission and, as has been mentioned, the capability to slide to 50 percent over pressure. The use of the partial arc admission resulted in reduced throttling losses under normal operating conditions (two turbine operation) and improved single turbine operation. At 8 kilograms per sq. cm (115 psig) throttle pressure at (or near) the first valve point, the larger valve is fully open and the smaller valve is fully closed. Under these operating conditions, each machine provides about $40 \mathrm{MW}$ of net output (McKay and Tucker, 1985). 
When only a single turbine generator is operable, the smaller valve is opened and at 11.6 kilograms per sq. $\mathrm{cm}$ (165 psig) throttle pressure, one turbine can produce approximately 80 MW net (Blachly, 1985).

The use of a large multi-pressure condenser results in a low average condenser pressure and further enhances efficiency when combined with the large cooling tower (McKay and Tucker, 1985). A condenser bypass allows full steam flow through the condenser of the operating unit and the use of the entire cooling tower so that design back pressure can be maintained during single turbine operation (McKay and Tucker, 1985).

\section{NCPA \#I}

The Northem California Power Agency 110 MW ( 2 x 55 MW) Geyser Plant \#1, completed in 1983, purchases steam on a per pound basis. NCPA requires approximately 25 percent less steam (6.8 kilograms or 15 lbs.) to produce a kilowatt than similar vintage PG\&E power plants $(9.1$ kilograms or $20 \mathrm{lbs}$.) where steam contracts call for payment on a mills per kilowatt-hour produced basis. The higher efficiency of the NCPA plant \#1 is achieved through the use of highly efficient turbines and through the use of larger cooling towers with a separate cooling system for each turbine generator unit.

Contract terms and ownership arrangements have had a significant impact on design and efficiency of new geothermal operations at The Geysers. However, potentially more important from a total energy perspective are innovative solutions to increase power production from hot water resources which are far more abundant than are dry steam resources. In fact, estimates by the United States Geological Survey indicate that $90+$ percent of the geothermal resources in the United States are water dominated and of these 80 percent are between $100^{\circ} \mathrm{C}$ $\left(212^{\circ} \mathrm{F}\right.$ and $204^{\circ} \mathrm{C}\left(400^{\circ} \mathrm{F}\right)$.

Utilization of hot water resources can be accomplished through the use of either flash or binary technology, dependent upon temperature and the chemical characteristics of the resource. Single flash technology has been well demonstrated throughout the world on hot water resources generally in excess of $177^{\circ} \mathrm{C}\left(350^{\circ} \mathrm{F}\right)$. However, below $177^{\circ} \mathrm{C}\left(350^{\circ} \mathrm{F}\right)$ single flash technology is being replaced by double flash plants or binary plants which utilize secondary working fluids such as freon, propane, isobutane, or isopentane. Plants which utilize these technologies are now operating in the United States in Califormia, Nevada, and Utah.

\section{Non-Geysers Case Histories}

\section{Heber Binary}

The Heber Binary plant in the Imperial Valley of southern California is the biggest and was designed to be the most significant demonstration of the use of binary technology in the United States (Figure 4). The plant was designed to operate efficiently at $182^{\circ} \mathrm{C}\left(360^{\circ} \mathrm{F}\right)$ using a supercritical Rankine cycle with a 90:10 mixture of isobutane and isopentane as the working fluid. The turbine generator is rated at $70 \mathrm{MW}$ gross output. Auxiliary load amounts to $23.4 \mathrm{MW}$ giving a net output of $46.6 \mathrm{MW}$. Brine flow at full output was to be 3.5 million kilograms (7.7 million lbs.) per hour (Nelson, 1985).

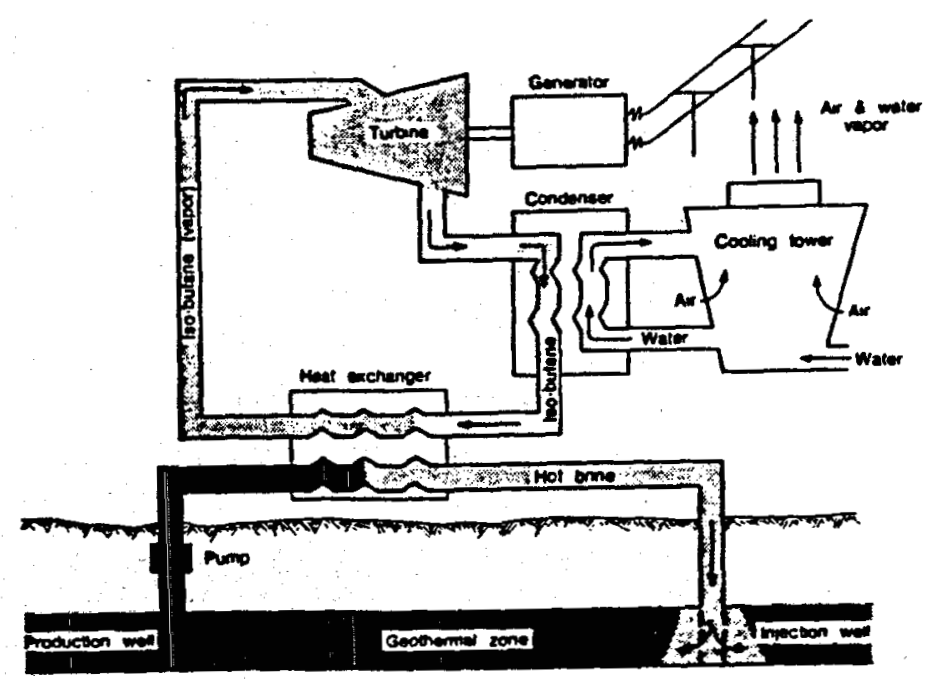

Figure 4

Binary Cycle Power Plant

The power cycle was designed to use floating cooling wherein turbine back pressure would fluctuate with ambient wet bulb temperature in order to maximize power generation at any given atmospheric condition. Floating cooling results in improved average efficiency with a resulting reduction in brine flow requirement. Obtaining maximum output from a given brine flow is extremely important as the price of brine is based on a per million Btu basis.

Availability is increased through the use of a 100 percent capacity brine bypass line which allows the heat exchangers 
to be bypassed in case of a plant trip or during plant start-up. However, the plant never operated at much above 50 percent of rated capacity due to brine supply problems, and no determination of actual obtained efficiency was determined before the plant was taken out of service in 1987. The future of the plant (as of May 1989) is still in doubt.

\section{Mammoth-Pacific}

Another important demonstration of binary technology is taking place in Mammoth Lakes, Califomia. The Ben Holt Company built the Mammoth-Pacific $7 \mathrm{MW}$ (net) modular binary power plant. The plant utilizes isobutane as the working fluid in the Rankine cycle. The resource temperature is $165^{\circ} \mathrm{C}\left(330^{\circ} \mathrm{F}\right)$. The plant is located on Magma property and Mammoth-Pacific pays royalties to Magma on both the sale of power and for use of the Magmamax binary process. This process was patented by Magma Power Company.

The plant is comprised of two $5 \mathrm{MW}$ nameplate capacity turbine generators. Cooling is provided through the use of two banks of dry cooling towers (air-to-air heat exchangers), each containing 11 sections. Condensation of the working fluid is based upon floating cooling with the condensing temperature allowed to vary with changes in the inlet air temperature. Floating cooling results in lower than average production during the summer, and higher than average output in the winter. Favorable atmospheric conditions during the remainder of the year make up for the low summer production. The constant rate contract does not include time of day or time of year rate differentials. Average annual conversion efficiency, in this case, overrides single point design conversion efficiency considerations. The net result is a higher total annual power output than if a single high air temperature was chosen as the design point for year-round operation (Campbell and Holt, 1985).

The plant has operated above design specifications and maximum gross power output has been $11 \mathrm{MW}$ while average net output has exceeded $8 \mathrm{MW}$. This amounts to 1 $M W$ in excess of design. It is estimated that even greater output could be obtained from the existing turbines if the isobutane system as well as the heat rejection systems were not already operating at full capacity. During the period December 1985-December 1986, the plant operated at an average capacity of ca $7.3 \mathrm{MW}$ or $0.3 \mathrm{MW}$ over design (Asper, 1986).

\section{ORMESA I}

ORMESA I located at East Mesa in the Imperial Valley of southern Califomia. It consists of $261.25 \mathrm{MW}$ (nominal) ORMAT Systems, Inc., organic Rankine cycle units. The units are arranged in three tiers in order to allow for maximum use of the resource and maximum energy extraction. The first tier consists of two sets of eight units. The inlet temperature to the units is $154^{\circ} \mathrm{C}\left(310^{\circ} \mathrm{F}\right)$ from the level 1 units the water enters the 8 level 2 units at $116^{\circ} \mathrm{C}$ $\left(240^{\circ} \mathrm{F}\right)$ and finally the water enters the 2 level 3 units at $93^{\circ} \mathrm{C}\left(200^{\circ} \mathrm{F}\right)$. In this way maximum energy extraction is accomplished (Miller 1987; Yahalom, 1987). Even higher efficiency could possibly be achieved if the working fluid were matched to the inlet temperature. However, the extra cost of handling three working fluids is not offset by the increase efficiency (Yahalom, 1987).

\section{Desert Peak}

The Desert Peak power plant project provided an altemative design concept for utilizing moderate temperature geothermal fluid $\left(163^{\circ} \mathrm{C}, 326^{\circ} \mathrm{F}\right)$ to generate electricity. The Desert Peak plant was designed to utilize the Biphase Rotary Separator Turbine (RST) to obtain maximum efficiency in the most cost-effective fashion. The RST turbine had been fully tested at Roosevelt Hot Springs in Utah by the Electric Power Research Institution and had operated successfully at the $>200^{\circ} \mathrm{C}\left(400^{\circ} \mathrm{F}\right)$ resource temperature.

The choice of the Biphase system with a wet cooling tower system was made only after single flash, double flash, and binary systems as well as wet and dry cooling systems were fully evaluated by Phillips Geothermal, the field developer. Given the $163^{\circ} \mathrm{C}\left(325^{\circ} \mathrm{F}\right)$ resource temperature and meteorological conditions at the plant site, the RST system was calculated to have distinct cost and performance advantages over other systems evaluated. Among the advantages of wet over dry cooling was a reduction in parasitic load of nearly $750 \mathrm{~kW}$, and an increase in average power produced of approximately $2.8 \mathrm{MW}$. The use of floating cooling as compared to constant cooling was expected to result in a 10.5 percent increase in net power. The RST system was expected to result in a net increase in conversion efficiency of only .21 percent over a binary system, but with the RST, a capital cost savings in 1983 dollars of $\$ 7,200,000$ over a binary system could be realized. In comparison with a dual flash plant, the Biphase system was expected to provide an advantage in gross power output approximately equal to the parasitic load or an increase in net power production of approximately 10 percent (Cerini, et 
al., 1984). In comparison to a single flash plant, the RST system was expected to result in a $30+$ percent increasse in power production. Unfortunately after the completion of extended test runs the RST was found to be the soutce of several problems, among which disposal of large quounts of water forced the discontinuation of its use (Benoi, 1987). The plant is now operated as a standard single filsh unit. The difference in inlet temperature and pressure/between Roosevelt and Desert Peak is thought to be the frain reason the RST was unsuccessful at Desert Peak.

\section{Conclusion}

Efficiency innovations being demonstrated in these six geothermal power projects indicate the sighificant increases in power production possible through ad ances in engineering and design and reflect chanfing ownership and operation considerations. Geothermal generation is clearly becoming increasingly cost competiti e with conventional and other renewable generating techy blogies. In addition, innovative design for efficient prodyction from low and moderate temperature resources coyld make cost-effective power generation viable at many aqditional sites.

\section{Availability Through Innovation}

\section{Introduction}

Geothermal power plants have, as discussed above, become increasingly efficientin order to maximize electrical production from each pound of steam produced or purchased. These increases $p$ efficiency have been the result of incentives created by chfnges in contracts and ownership and operation arrangemens s as well as design changes. However, in terms of ensaring optimum net revenue from a project, it is essential that the project not only be capable of highest possible convegsion efficiency, but also that the generating facilities by designed to provide maximum availability. Availabjlity refers to whether a plant was capable of generating electricity during a given period of time regardless of thether it actually did so (Fesmire, 1985). Availability has, if fact, become so important that many contracts between independent power producers and utilities contain clauses hich give bonuses for availability above certain levels. Shch clauses assure not just energy to the utility, but capfcity, and hence are called capacity payments.

\section{Case Histories}

Santa Fe \#I

Increased availability is achieved through designs which ensure highest possible flexibility and reliability in plant operation. The Santa Fe Geothermal Plant No. 1 is an interesting example of a plant which has obtained both high capacity and availability through an innovative approach.

The Santa Fe plant (originally designed for Occidental Geothermal) was designed by Stone and Webster Engineering Company. Since Occidental was to be both the steam supplier and the operator of the power plant, the plant was designed to meet PURPA criteria, i.e., a maximum production of $80 \mathrm{MW}$ of net power with maximum availability. This reflected the owner's primary objective to maximize production and therefore revenue.

In order to obtain highest possible availability, the plant was designed to incorporate redundancy in most active components, including a redundant spinning turbine generator (Fesmire, 1985). Although the original design called for a single four-flow turbine, the use of such a turbine would require two spare rotors, average performance below design because of turbine fouling, and frequent outages since the plant would, of necessity, be off-line while a rotor was being replaced for refurbishing. Because of the problems of decreased efficiency and/or availability which the four-flow turbine would create, Stone and Webster investigated the merits of using twin two-flow machines instead of a single four-flow machine. Their evaluation included cost-effectiveness in terms of additional capital cost versus increased availability and resulting net revenue and included an evaluation of O\&M requirements.

The original four-flow machine had been sized at 96.8 MW--80 MW of net salable power plus 10 percent for house load plus 10 percent allowance for average turbine fouling. In order to duplicate the output of the single unit, each of the two-flow machines was sized to produce $48.4 \mathrm{MW}$ when both units are operated at the same time. However, because the cooling towers and circulating pumps were sized for 96.8 $M W$, the cooling system had significant excess capacity when the units were operated singly. Accordingly, each turbine, when operated singly, would be capable of $54 \mathrm{MW}$ when operated at 8.1 kilogram per sq. $\mathrm{cm}$ (115 psia) inlet pressure and $7.6 \mathrm{~cm}$ ( 3 inches) $\mathrm{Hg}$ exhaust pressure. The economic analysis indicated that the additional revenue produced through higher average power generating capability, and the savings associated with one less spare rotor, would more than justify the additional cost of the 
second generator and associated equipment (Fesmire, 1985). Although the higher availability provided by being able to run one turbine generator at $54 \mathrm{MW}$ was very attractive, additional analyses indicated that even greater capacity and availability could be achieved through the purchase of two turbine generators, each rated at $48.5 \mathrm{MW}$ gross capacity at 8.1 kilograms per sq. $\mathrm{cm}$ (115 psia) inlet pressure, $7.6 \mathrm{~cm}$ (3 inches) $\mathrm{Hg}$ exhaust pressure, but also capable of $88.2 \mathrm{MW}$ at 11.6 kilogram per sq. cm (165 psia) inlet pressure, and $5 \mathrm{~cm}$ ( 2 inches) $\mathrm{Hg}$ exhaust pressure (see discussion of partial arc admission above). The incremental cost of machines capable of operating at 11.6 kilograms per sq. $\mathrm{cm}$ (165 psia) is again more than offset by the additional revenue produced; in fact, it has been calculated that two weeks' additional generation per year covers recovery of the additional capital cost (Prideaux, 1985). This correlates to downtime for scheduled maintenance on a single machine. The additional costs associated with operation of the steam field operation at the higher pressure (11.6 kilograms per sq. $\mathrm{cm}$ [165 psia]) are negligible.

In addition to the use of redundant active components, the Santa Fe plant has also increased availability through use of a turbine bypass which allows steam to be routed around the turbine directly to the condenser. The use of the turbine. bypass allows for constant steam flow to the plant in case of a turbine trip or other disturbance. The units can then be brought back on-line more quickly once the cause of the trip or other disturbance is resolved since no warm-up period is required. Without the turbine bypass, the wells would have to be shut in and/or vented to the atmosphere, and it would take several hours to bring the wells and plant back to full production. Although this was the first use of such a bypass at The Geysers, engineers and regulators quickly recognizing its value in increasing availability and reducing unabated steam emissions.

The Santa Fe plant has more than lived up to expectations. During the first year of operation it achieved a capacity factor of 98.6 percent of its $80 \mathrm{MW}$ operating permit and an availability factor of 99.9 percent. Such performance is believed to be without precedent in commercial power plants and the plant has continued to operate with very high capacity and availability.

The use of multiple turbine generators has also been incorporated into the design of the Mammoth-Pacific plant and into the design of several of the plants utilizing small modular units such as those produced by ORMAT Systems, Inc. The Mammoth-Pacific plant, for example, has had an availability of over 90 percent (Asper, 1988). None of the other plants studied, however, have the ability to operate at increased inlet pressure so as to be able to approach the availability and capacity which has been demonstrated by the Santa Fe plant. However, the use of multiple turbine generators does provide a high degree of flexibility in operation and the continuing production of significant amounts of power, even when some units are inoperable because of equipment failure or scheduled maintenance.

\section{ORMESA I}

ORMESA I, IA, and II, which are located at East Mesa, all consist of multiple 1.2 MW ORMAT system andorganic Rankine cycle modular units. The units are arrangef into several tiers in order to allow for cascaded use of the resource and maximum energy extraction. In addition, if one or more units in a tier must be taken out of seryice for repair or routine maintenance, the flow which would normally supply those units can be rerouted to the renfaining operating units to increase net output. The result is toprovide maximum availability and, in fact, the plafts have operated with an availability and capacity factors in the high 90 percent range (Miller, 1989).

\section{Coso}

California Energy Company's Coso project: consists of nine operating units, with three uhits comprising each plant. The project plants are Coso Nayg 1, Coso Navy 2, and Coso BLM East and West. Net outpyt from ench plant will be ca $80 \mathrm{MW}$ - the maximum allow able under PURPA. Each of the plants integrates the ope ation of the three units and, although each unit has a rafed net capacity of $27 \mathrm{MW}$, if one unit is down for maintenghce, the remaining two units can produce a total net outpy of ca $65 \mathrm{MW}$. After approximately two years of operating experience, the plants have an established availability in the trigh 90s (Rosser, 1989).

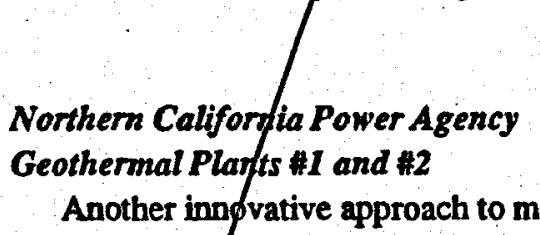

Another innovative approach to maximizing capacity and availability has been incorporated into the design and operation of the well field which supplies the Northem California Power Agency (NCPA) Geothermal Plants No. 1 and 2. The two facilities are twin $106 \mathrm{MW}$ (net) plants treated as single power generation facility dependent on one unifigd steam field. Although each plant is supplied from a distinct area within the steam field, the two steam fields afe connected through an intertie. The intertie is large 
enough to allow the passage of steam in either direction at a rate sufficient to maintain full operation at either plant site. Because distance from wellhead to turbine is a key determinant of a steam supply's cost effectiveness, it is planned that neither power plant would be supplied with steam exclusively through the intertie for an extended period of time. The availability of the intertie, however, provides a method by which short term natural variations in steam supply and pressure are easily accommodated. The intertie also provides a source of back-up if wells in either portion of the field have difficulty in providing full steam supply. NCPA Plant's \#1 and \#2, which went on-line in 1983 and 1985-86, respectively, have been operating at a steam availability approaching 100 percent through this arrangement (Moore,1986).

\section{Conclusion}

New geothermal plants contain effective design innovations. Examples include redundant turbines, multitiered modular plants, and steam field interties. Results are positive as shown in high plant availability and capacity factors. Geothermal independent power production is providing the highest possible plant capacity and availability. This ensures maximum revenue to both the plant owner and operator, as well as to the well field developer, regardless of ownership structure. In a similar manner, if geothermal plants are operated in this fashion by a utility, high availability can provide a direct benefit to the stockholders and/or ratepayers.

\section{Reducing Environmental Impacts}

\section{Introduction}

Ensuring that geothermal power generating plants create minimum environmental impacts has received major emphasis during the design, construction, and operation of the most recently completed geothermal projects. While some of the emphasis on environmental compatibility is mandated by the passage of increasingly stringent environmental standards, engineers have also correctly observed that impact avoidance is often less costly than mitigation. Similarly, some higher capital design costs can be justified by lower operational costs. In addition, both resource developers and plant operators have also become much more aware of the importance of a good neighbor policy. Many measures taken to protect the environment also result in increased plant and well field efficiency, or vise versa.

The environmental issues most often associated with geothermal development include release of air and water pollution, water consumption, land use, and visual impacts. The extent to which environmental impact mitigation must be incorporated into well field and plant design and operation is, however, almost entirely dependent upon the geographic location and the specific characteristics of the resource. For example, concentration of such airborne pollutants as $\mathrm{H}_{2} \mathrm{~S}$ can vary from at or below the detection limit to $1,200 \mathrm{~g} / \mathrm{MW}$ produced or greater (Bloomquist, et al., 1985). In a like manner, the amount of total dissolved solids (TDS) in the fluid can vary from a few hundred PPM to greater than 350,000 PPM. While both air and water pollutants are very resource specific, conflicts in land and water use are geographically and culturally dependent. Land use must be kept to an absolute minimum in such rich agricultural areas as the Imperial Valley of southern Califomia, whereas few restrictions on land utilization apply in the deserts of Utah and Nevada. In many areas, all available waters have been appropriated for agricultural and domestic use. This requires geothermal plant operators to use condensate, if available, or dry cooling.

The visual impacts that a generating facility, associated well field equipment, and cooling tower plumes will have, are highly dependent upon proximity to population centers or areas of high recreational usage and/or extreme natural beauty. The most critical site surveyed during the course of this study in terms of visual impacts is undoubtedly that in the resort community of Mammoth Lakes, Califomia.

\section{Reducing Impacts of Alrborne Pollatants}

Concerns over emissions of noncondensible gases (e.g., $\mathrm{H}_{2} \mathrm{~S}$ ) and other airbome pollutants (e.g., boron, mercury, arsenic, and other trace metals), have been responsible for a great deal of research resulting in a number of innovative design measures.

$\mathrm{H}_{2} \mathrm{~S}$, which is a problem even in low concentrations because of its highly detectable odor and because of its toxicity in high concentrations, has been the focus of much of this work (Bloomquist, et al., 1985). At present, the Stretford process is the most common, efficient, and costeffective mechanism used to control $\mathrm{H}_{2} \mathrm{~S}$ emissions at The Geysers in northem California. Secondary $\mathrm{H}_{2} \mathrm{~S}$ abatement is often provided through a hydrogen peroxide/chelating agent/catalyst system (Fesmire, 1985). The Dow process is 
however gaining in acceptance because it does not produce a hazardous solid waste product but "bums" the sulfur instead (Buenger, 1989).

The use of the Stretford and hydrogen peroxide abatement systems has significantly reduced one of the greatest environmental concerns associated with resources containing high concentrations of hydrogen sulfide. Unfortunately, these systems function only if the steam is directed through the condenser. Because of this, a major concern has been the unabated release of hydrogen sulfide during a turbine trip or other malfunction causing steam to be vented to the atmosphere (stacking).

In the case of both the SMUDGEO \#1 and Santa Fe plants at The Geysers, this problem has been significantly reduced by incorporating a turbine bypass into the system design. The turbine bypass allows the full steam flow to be routed past the turbine directly into the condenser and the hydrogen sulfide abatement system (Fesmire, 1985; Tucker, et al., 1980).

The designers of the NCPA (Northem California Power Authority) geothermal plant \#1 did not incorporate a turbine bypass into their plant desigo because of cost consideration, but instead use a computerized well shut-in stacking and start-up system which provides maximum flexibility in well operation while minimizing unabated release of hydrogen sulfide to the atmosphere (Fontes, 1985; Anderson, 1986). In 1986, the wellfield supplying Unit 15, which is operated by Pacific Gas and Electric Company at The Geysers, was equipped with a computerized well shut-in/start-up system in order to meet the environmental standards for $\mathrm{H}_{2} \mathrm{~S}$ emissions. The system is capable of ramping down the steam field to predetermined levels of flow within ten minutes of being tripped off-line or the advent of stacking. In a like manner, the wells can be ramped up automatically when additional steam flow is required (MacPhee, 1987).

Another design option being considered by many operators to minimize noncondensible gas (NCG) release is to capture the gas and inject it together with the condensate, and/or spent brine, back into the reservoir. In the case of the COSO project, the release of any air pollutants was a major concem at the China Lake Naval Weapons Testing Center. California Energy Company in order to comply with emission standards adopted a system by which approximately 100 percent of the noncondensible gas is injected together with the brine and steam condensate cutting air emissions to nearly zero (McClain, 1989; Rosser, 1989).
Besides $\mathrm{H}_{2} \mathrm{~S}$, boron appears to be the only other major airbome pollutant with potentially serious effects upon the environment. Boron, unlike hydrogen sulfide, is not found as a constituent of the non-condensable gas, but rather as a constituent of the condensate and, as such, escapes as drift droplets from the cooling towers of those plants which use geothermal condensate for cooling water (Bloomquist, et al., 1985). Resolution of the problems associated with boron release as a result of cooling tower drift has not been given a great deal of emphasis. However, because the design of the SMUDGEO \#1 and Santa Fe facilities both incorporate extremely efficient condensers and associated heat rejection systems, steam plumes and cooling tower drift are minimized in size and occurrence, thus reducing boron release (Tucker, 1980; Fesmire, 1985; and Stone and Webster Engineering Corporation, 1983).

In addition to playing an important role in improving system efficiency, avoiding atmospheric discharge of steam, and decreasing boron release, the design and operation of SMUDGEO \#1 and Santa $\mathrm{Fe}$ has also minimized another critical environmental concern--the visual impact of cooling tower plumes.

Another major design option to minimize all forms of air pollution from geothermal power plants is the utilization of a binary system (Figure 4). In the case of the binary system, the brine never comes into contact with the atmosphere. In binary systems, for example, at ORMESA I, IA, and II, Steamboat Springs, Stillwater, and Mammoth Lakes, the geothermal brine is confined under pressure from the plant's production well to the-injection well (Asper, 1985; Miller, 1988 ). Heat exchangers transfer the heat from the geothermal brine to a secondary working fluid which is vaporized to drive the turbine.

An imovative solution to the need for cooling in binary plants has been reached at the Mammoth-Pacific Plant in Mammoth Lakes, Califomia, through the use of dry (air-toair) cooling towers (Campbell and Holt, 1985). The use of dry cooling towers results in a reduction in overall plant efficiency during the summer months; however, since Mammoth Lakes is a peak winter load area, the increased efficiency of winter operation more than justifies the use of dry cooling (Asper, 1985). In addition to eliminating consumption of cooling water, this system has also eliminated cooling tower drift and vapor plumes (Asper, 1985). Thus the Mammoth-Pacific plant is essentially free of environmental impacts and, although within a mile of the highway into Mammoth Lakes, one of the most popular ski resorts in the United States, it is unnoticed by the $40,000+$ 
persons who visit the area each week during the winter ski season.

Dry cooling was also incorporated into the design of the Steamboat Springs ORMAT facility. Originally the plant was designed to use wet cooling during the warm summer months and air cooling during the dry winter months, when cooling tower drift could have been a hazard to near by highway transportation, the plant was, however, forced to go to 100 percent dry cooling due to a lack of available water rights and chemical problems associated with using the geothermal brine for cooling (Miller, 1987; ORMAT, 1989).

\section{Reducing Impacts Upon Water}

Water, being the medium by which geothermal beat is transferred to the surface for utilization, can often contain high concentrations of potentially hazardous materials. In addition, large volumes of ("nongeothermal") water are often required for use in power plant cooling systems or as the heat transfer medium in Hot Dry Rock projects.

The greatest potential impacts upon surface and near surface groundwater are high concentrations of silica and/or calcium carbonate together with potentially toxic amounts of $\mathrm{NH}_{3}, \mathrm{H}_{2} \mathrm{~S}, \mathrm{Hg}, \mathrm{B}$ and As, which are often found in geothermal brine (Bloomquist, et al., 1985). The total amount of these substances varies from a few hundred PPM to several hundred thousand PPM, dependent upon the characteristics of the resource. There may even be substantial differences from well to well within the same reservoir. Because water is merely the beat transfer medium, and little or no actual consumption occurs, substantial amounts of water ( 76 million liters [ 20 million gallons]) per day per $100 \mathrm{MW}$ for a typical flash plant must be safely handled so as not to contaminate surface and near surface groundwater and eventually be disposed of in an environmentally acceptable manner (Bloomquist, et al., 1985).

Although extensive surface disposal has been utilized in some parts of the world, including Mexico and New Zealand, nearly all plants now in operation utilize injection as the primary disposal mechanism for both spent brine and steam condensate. Besides the obvious advantage of using injection as a means to ensure that geothermal brines will not contaminate other waters, injection can increase the useful life of the reservoir and prevent or significantly reduce the effects of land subsidence. Even in areas with dry steam such as The Geysers, there is an increasing awareness of the value of injection as a means of prolonging the life of the reservoir (Prideaux, 1985). The highly efficient condensing systems, which are employed in the SMUDGEO \#1 and Santa Fe plants, have significantly increased the amount of condensate which is available for injection (Prideaux, 1985).

The increased use of binary power plants has also significantly reduced the risk of contaminating surface and near surface groundwater as the geothermal fluids are confined and under pressure from the production well to the injection well. However, because most binary plants release no geothermal brine at the surface and no condensate is produced, this makes them totally dependent upon surface or near surface groundwater as the source of cooling water. The availability of such water may be extremely limited in arid regions or in areas where all water has been appropriated for other uses, such as agricultural irrigation. For example, the Heber binary plant required 15,000 liters $(4,000 \mathrm{gpm})$ of cooling water at design conditions make up for full summer load. This water was being purchased from the Imperial Irrigation District at a cost of $\$ 0.4 /$ cubic meter or approximately .71 mills per $\mathbf{k W h}$ (Ludolph, 1985).

\section{Improved Land Use}

Although land has not been of major concern in most geothermal areas, it has become a subject of increased concern as geothermal development has spread to areas of high agricultural, timber, or recreational values.

Historically, development at The Geysers has resulted in direct vegetation loss of approximately .40 hectares ( 1.0 acre) per MW of power production, including plant and well field facilities. Recent trends have been to reduce the total area required for the plant and well field facilities. For instance, at the SMUDGEO \#1 facility, only 3.8 hectares (9.6 acres) have been affected for $72 \mathrm{MW}$ of net production (Stone and Webster Engineering Corporation, 1985).

In contrast to the traditional amounts of acreage that have been utilized at The Geysers are the two ca $50 \mathrm{MW}$ net Heber plants. The Heber Flash Plant and the Heber Binary Plant each occupy an approximately 8 hectare $(20$ acre) site with each plant needing nearly one additional hectare ( 2 acres) approximately one mile from the plant site as an injection island (Sones, 1985; Ludolph, 1985). In both instances, the production island is located within the 8 hectare ( 20 acre) plant site. The use of directional drilling at both the production and injection islands has minimized total land utilization in this highly fertile part of southem Califomia's Imperial Valley.

Another important trend in reducing land use is the use of modular wellhead units. These units generally produce 10 
MW or less of net output and are primarily shopmanufactured as opposed to constructed on-site. The Ben Holt Company's Mammoth-Pacific facility at Mammoth Lakes, California, was the first major installation of a modular wellhead generating plant. The entire lease block is only 38 hectares ( 96 acres). The $7 \mathrm{MW}$ plant is located on 0.6 hectares ( 1.5 acres) while an additional 3.6 hectares $(9$ acres) are dedicated to roads, wells, and pipelines. With the addition of a second planned unit, approximately 8 hectares (20 acres) will be dedicated to the generating plants and well field and associated facilities (Asper, 1985). Of this 8 hectare ( 20 acres), however, only the plant site, access roads, and well pads have resulted in direct vegetation loss. The use of modular wellhead units can be expected to increase in high land use areas, and their use will most likely result in minimal land disruption.

\section{Reducing Visual Impacts}

Geothermal power generating facilities are, in most instances, major industrial complexes which can be expected to have a significant visual impact upon surrounding areas. In addition to the industrial nature of the facility, geothermal plants must be co-located with the resource which, because of the geological nature of its occurrence, is most often found in areas of extreme scenic beauty -mountainous areas of volcanic or tectonic origin.

The major sources of visual impacts are drilling rigs, pipelines with expansion loops, generating plants, cooling towers, steam plumes, and transmission towers and lines. The use of directional drilling from production and injection islands has reduced the number of well pads and the amount and complexity of well field piping. Plant siting is based, to the greatest extent possible, on environmental as well as geotechnical grounds, and facilities are constructed, painted, and landscaped to have the least distuptive impact upon the visual character of the area.

The greatest visual impact resulting from geothermal power generation, however, is generally the steam plumes which emanate from the cooling tower and which may be visible for distances of several miles, depending upon meteorological conditions. The visual impact of steam plumes has, however, been significantly decreased or eliminated through the use of two innovative applications of proven technologies-more efficient heat rejection systems and dry cooling.

At SMUDGEO \#1 in The Geysers, the large capacity of the condenser and cooling tower was designed to obtain maximum efficiency in steam utilization because of the terms of the stream contract. However, an additional benefit of the heat rejection system, which was designed to obtain an extremely low back pressure, has been to nearly eliminate the cooling tower plume even when temperatures are below freezing (Prideaux, 1985). In fact, it is estimated that the plumes have been reduced by as much as 75 to 80 percent (Yueh, 1986). In critical siting cases, this could prove to be extremely beneficial or a necessity.

At both the Mammoth-Pacific $7 \mathrm{MW}$ plant and the 5.5 MW ORMAT Steamboat project, dry cooling towers are utilized which completely eliminate the existence of a steam plume (Asper 1985, Miller, 1988). Although current designs are limited to smaller geothermal plants, benefits of dry cooling towers include elimination of plumes, associated cooling tower drift, and associated airborne pollutants. The plants are essentially free of environmental impacts due to no cooling water consumption, no visible plume, and no atmospheric contact with brines.

In the case of Mammoth-Pacific, the cooling towers were also selected so as to be in compliance with county regulations which prohibited the construction of facilities greater than 20 feet tall (Lyster, 1985). Although this was one of several critical criterion for the Mammoth project. undetectable operation within a mile of the highway into California's largest ski resort clearly demonstrates geothermal compatibility with the most sensitive of environments.

\section{Conclusion}

The design and operation of geothermal power generating facilities in the United States has undergone a major revolution since the early days at The Geysers. The majority of that revolution occurred beginning in 1980.

The changes that have occurred are a result of several factors, among which the passage of the Public Utility Regulatory Policy Act (PURPA) of 1978, the Energy Tax Act of 1978, and the 1980 Windfall Profit Act are probably most significant. These important pieces of legislation have resulted in a new alignment of traditional resource developer/utility roles. Resource developers are no longer satisfied nor constrained (depending upon corporate philosophy or perspective) to merely sell geothermal brine or steam to a generating utility. Instead, they often consider plant ownership and operation a natural extension of their business, with the utility serving only as the marketer of electricity. Utilities, on the other hand, have begun to consider investment in resource exploration and development to ensure competitive "fuel" prices and market 
positions. Utility subsidiaries are often the vehicles used to accomplish this although some utilities, such as Portland General Electric, Seattle City Light and the Eugene Water and Electric Board, have made direct investments in leases and/or exploration.

Improved generation efficiency has been mandated by steam contracts which call for payment on the basis of pounds of steam delivered rather than on a percentage of revenues from electricity sales. Similarly, when the field developer and the plant operator are the same, there is a clear recognition of the value of each pound of steam produced (Fesmire, 1985). Higher efficiency has been achieved through turbine bypass systems, computerized well field operation, the use of larger heat rejection systems, and more efficient turbines. Secondary benefits have been decreases in airborne pollutants, increases in available water for reservoir maintenance, and decreases in the visual effects of cooling tower plumes.

Engineering design, driven by desire to maximize economic efficiency, has also sought highest capacity and availability factors. Many of the newest plants have been able to achieve these in the high 90 percent range. High availability has been ensured through redundancy of most active components. For example, in the case of the Santa Fe plant at The Geysers, this includes a redundant (i.e., "twin train") turbine generator (Fesmire, 1985). In the case of Mammoth-Pacific, Steamboat Springs, ORMESA, and COSO, it means multiple modular units which vary in size from $800 \mathrm{~kW}$ to $27 \mathrm{MW}$.

Thus, through innovative improvements in plant design and plant and well field operation, many of the geothermal generating plants built since 1980 are operating with extremely high capacity and availability factors while, at the same time, optimizing the use of geothermal steam or brine with decreased environmental impact. The MammothPacific binary plant is one of the classic examples of this with benefits occurring to the developer, utility, consumers, and the long term productivity of the field.

The cases sited above can be regarded as state-of-the-art technology for siting or evaluation purposes. Even on low grade resources, small binary systems are demonstrating technical, environmental, and economic advantages in spite of less profitable fluids. As confimation/testing facilities, these small plants incur minimal risks and may offer significant insight into the feasibility and operating parameters of larger commercial scale plants. In the case of
ORMESA, this is continuing to happen with four plants totaling over $50 \mathrm{MW}$ (net) expected to be in operation by the end of 1989.

In conclusion, geothermal power generation is continuing to prove itself a bighly reliable, cost-effective source of electricity. Comparison of cost and reliability criteria suggest geothermal to be a source of electricity which will almost surely play a major role in meeting future energy demands in an environmentally acceptable manner as it continues to gain in acceptance by the financial community and utility purchasers. 


\section{Chapter 3}

\section{Financing: The Banker's Perspective}

\section{Introduction}

The authors earlier performed research into plant engineering. construction, and the affects of the independent power market on new geothermal production. This research indicated a trend toward growing financial community influence over power plant development. Following this line of investigation, the financial community was interviewed for perspectives on geothemal and other power plant development. The following is a synopsis of the findings obtained through interviews with six of the largest financial institutions in the United States who have extensive experience in the financing of geothermal as well as other altemative energy projects.

Listed below are specific areas evaluated by the investment community to determine the viability of geothermal or other alternative energy projects. Many of the topics (construction techniques, developers' capabilities, engineering design, equipment specifications, and power sales agreements) were covered in Chapters 1 and 2 .

Highlights of each topic, as reiterated by the bankers, are summarized below.

Construction
Developers
Engineers
Equipment
Financing
Fuel Supplies
Operation \& Maintenance
Power Sales
Regulation

\section{Construction}

Big name constructors are preferred and often a requisite of obtaining financing. Construction contracts should be fixed price, a technique learned from cost overruns at many utility power plant projects. Tight construction contract clauses are also required by banks. Completion guarantees and formulae for rectifying any problems (without using the banks' money) are nearly always required.

\section{Developers}

Experience, equity, or both are the best developer attributes. Alliances of motivated participants with expertise in particular areas are most desirable. Examples might be a resource company with a proven reservoir or a construction firm with equity in the plant. Regardless of experience level, significant resource work, i.e., discovery and step out production wells, should be completed before approaching the bank.

\section{Engineers}

Recognized consulting engineering firms with considerable experience, preferably in geothermal plant design, are preferred.

\section{Equipment}

Equipment should have a proven track record in similar applications. Performance warranties for either critical components or the whole plant are highly desirable.

\section{Financing}

Many energy projects can be financed based solely on verifiable resources (supply) and markets (demand). A strong, predictable cash flow supports project financing. Such projects are, however, often simply a collection of contracts, and contracts are only as good as the people behind them. The availability of financing is made easier if quality parties are behind the contracts. The credentials of those who present the project (and are affiliated with it) are important to the bank. Publicly-backed opportunities, e.g., county-sponsored garbage bumers, are among the most readily financeable projects.

\section{Power Sales}

A valid and viable power sales contract is assumed for all projects. Contract milestone or expiration dates must be reasonable. Not only should construction deadlines be attainable, but contract term should exceed loan length. The purchasing utilities' role is critical to reduce downside risks. 
Rates paid are examined for consistency with prevailing market prices, and for utility policy regarding contract extension in unforeseen circumstances.

Three power project topics critical-fuel supplies, operation and maintenance, and regulation-are discussed further due to their significance to the banking community. Following a close examination of these three finance aspects are the conclusions drawn from large commercial bank interviews.

\section{Fuel Supplies}

Ample, assured fuel supply for geothermal (and other small) power plants is increasingly emphasized. Plant fuel supply trends reflect the maturity of independent power in as much that since independent power plants have operated for significant periods, long term fuel supply issues have risen to the forefront as a major concern. Financial backing of geothermal projects is another force behind this trend. Bankers note that fuel availability and prices drive revenue requirements, and that revenue reliability depends on assured fuel supplies. Fuels drive revenues, without which, projects do not happen.

Selected fuel supply examples in the power industry are instructive. Hydroelectric power plants have somewhat unique fuels: river or stream flow. While the cost of such fuel is arguably free, the amount of fuel available to use is critical. For both hydro projects that store water behind a dam and "run-of-the-river" projects, river flow must be known to size the plant and predict revenues. If no records are available, project development risks are high.

Biomass (wood) fuel risks are typically reduced by having a wood products mill contract to supply the plant. Better yet is to have the mill be a participant in the power project. The Oregon Department of Energy's Small Scale Energy Loan Program has financed a number of biomass power plants. These plants are all subsidiary operations of lumber mills. Due diligence work on the loan requires that several scenarios of mill residue supplies be developed to determine whether the project can be financed. The first scenario is based on historically good production years. Other scenarios are based on percentages of operation, i.e., $75,50,25$, and no mill output. In the latter case, other nearby mills and forest residues would supply the plant. Such studies are part of the due diligence work which banks and financiers perform to assure adequate cash flow.

Municipal solid waste (MSW) or garbage supplies are another unique fuel source. This fuel can be directed to an energy recovery facility through local government action.
Such was the case with the Marion County (Oregon) MSW plant where local jurisdictions mandated that all MSW be delivered to the facility. Most project investors in these plants will require two supply actions: first, local government ordinances or laws requiring a jurisdiction's MSW flows to be controlled by one authority; and two, a comprehensive waste management program to be put in place. The second action results in conservative estimations of "fuel" supplies, less the net effect of recycling, and other waste reduction program impacts. The concem is assured supply so that the plant is not caught short of fuel if waste reduction programs are put in place or expanded after the plant is built.

Fuel risks associated with gas-fired cogeneration are now being reduced by securing natural gas fields in such gas rich supply areas as Canada and Texas (Weber, 1988).

Transportation access, however, must accompany gas field purchases; the two are inseparable if they are to be of real value. Lack of gas pipeline capacity constrained the development of power plants by independent power producers despite winning pids to supply one northeast utility (Kellerman, 1989). In another case, the financing of a new gas transmission line was part of a deal for a new cogeneration facility (Weber, 1988). But securing gas fields and pipeline availability are both new fuel supply techniques and were made possible by recent FERC decisions on deregulation. Previously, project developers were forced to depend upon the local natural gas utilities for fuel supplies.

Geothermal resources cannot be purchased on the open market, legislated into existence, nor bought from the local utility. Geothermal fuel risks are reduced by satisfying consulting engineers, in-house engineers, or both, as to reservoir deliverability over time. Deliverability may be defined as not what is in the reservoir, but the quality and quantity of the resource that can be delivered to the surface and power plant over an extended period of time. Experience at geothermal fields worldwide indicates that a decline in reservoir production is only a question of time (Budd, 1973). This may occur even if 100 percent brine injection is possible. Several examples of geothermal project financings indicate the fuel supply assurances sought by backers.

Swiss Bank financed the buy-out of leases supplying steam to the Northem California Power Agency (NCPA) plant at The Geysers. In this case, the steam supply was proven. Deliverability is well known as The Geysers is the largest producing geothermal field in the world. 
Negotiations centered around the value of the proven steam and the costs of future replacement wells, rather than on the adequacy of the reserves.

Bankers Trust financed the ORMESA I project in the Imperial Valley. Fuel supply assurances were satisfied by a 90 percent USDOE loan guaranty negotiated by the original developer. Federal government backing is sufficient to reduce most fuel risks even for plants on a new and unproven reservoir.

Another way to assure bankers of the adequacy of the geothermal resource is to demonstrate the capabilities of a the reservoir with multiple production wells. Such was the case of Oxbow Geothermal when it sought project financing for its Dixie Valley plant. Sufficient supply wells had been drilled prior to approaching the bankers, such that reservoir size, quality, and productivity was well established. In fact, the reservoir potential was greater than that required by the plant proposed. All that remained for the bankers to confirm was reservoir deliverability. For this task, Citibank used its staff of reservoir engineers located in Denver, Colorado. These engineers, with much experience in oil and gas reservoir analysis, applied their expertise to geothermal reservoir evaluation. Their results were confirmed by independent consultants-in this case, GeothermEx, Inc.

Finally, in all the above examples, consulting reservoir engineers were used extensively by the financial community. These individuals and firms provide independent, objective evaluation of all data about geothermal reservoir potential, reservoir characteristics, and deliverability. Geological, geophysical, and geochemical data; flow and storage capabilities; reservoir boundaries; deliverability; and recharge are all analyzed. Only then can a conclusion concerning the adequacy of the fuel supply be reached and financing secured.

\section{Financiers Emphasis on Operation and Maintenance}

Operation and maintenance (O\&M) on geothermal and other small power plants came into the spotlight in 1988. Since PURPA was passed in 1978, the independent power industry has evolved through youth and into early maturity. Plant O\&M trends reflect this as does the increasing financial sophistication of project developers. Commercial bank financing of geothermal projects has been a major force behind such trends. Banking experience affects developer perspective, power prices, project participation, and finally, opportunities to build plants.

The goal of developers in the first part of the decade was developing a project. Getting a plant financed and built was the focus. Now that projects are built, more attention to optimizing plant operation naturally follows. Creating a good "track record" is the goal of geothermal and other independent power firms as the key to future success and an ability to compete successfully for future power sales contracts.

Some developers will admit that operating the project may not be their strong point. One company, Environmental Power Corp., stated it succinctly: "We're developers, not operators," (Alternative Sources of Energy magazine, July/August 1988). Recognizing that difference, it is in the developer's best interest to obtain the services of the most qualified operators for it's plants.

As new power plants (regardless of fuel) have entered the market, real electricity prices have steadily dropped in most regions. Margins for profit are slimmer with the lower prices, making O\&M costs all the more critical. Some early plants very likely had higher than expected $O \& M$ costs due to a lack of operating experience. Little room for error in O\&M budgets now exists.

Developers are joining with partners and financiers in developing new power projects. Plant operating costs therefore get closer review by more parties. Investors and financiers are typically more conservative than developers. An experienced, big name company to operate the plant appeals to backers. Such appeal translates into slightly lower financing costs. Many developers are therefore willing to contract plant O\&M to third parties for strictly financial reasons.

Mission Operation and Maintenance Inc., a subsidiary of Mission Energy, Inc., has some guidelines for selecting a qualified O\&M service contractor. Besides operations experience, a good $0 \& M$ contractor should be able to effectively review plant design, participate in the plant startup, and conduct system checks. The contractor should perform a post boc analysis of significant events, including root cause analysis for future planning (Independent Power, 1989).

The increase in partnerships developing projects also points to another O\& $M$ trend: affiliates of financiers and/or partners are often highly competent facility operators. A vested interest in plant performance provides a motivating influence to the operators. Such motivation, in turn, provides security to financiers. Partners in recent plants include resource developers, utility subsidiaries, and construction firms. Examples of those entities providing O\&M services through subsidiaries are Magma Power (at it's Imperial Valley plants), Dravo Constructor's Plant Operating Group 
(at the Heber flash plant), ORMAT (at Steamboat Springs), and Barber Nichols (at Wineagle).

Good O\&M goes beyond maximizing current profits. This also includes the efficient use of the reservoir to prolong life and assure supply. Smart developers know that a good performance record will be critical to obtaining both contracts and financing for future plants. One lender, Baybank Boston, noted, assurance is needed "as our customers go on and develop new projects, that the importance of proper O\&M on existing facilities isn't overlooked." (ASE, July/August 1988) As electricity markets move towards bidding schemes, sophisticated financing is needed to keep costs to a minimum and meet bid specifications. Only those developers with good operational track records can obtain attractive financing terms so critical to winning bids.

The O\&M industry itself is maturing. As a result, there is increasing variety in O\&M contract options. Plant designers and constructors are good candidates for O\&M contracts, based on their ability to build the project and motivation to make sure it operates well. The previously cited example of project partners performing plant O\&M is based on that same motivation.

Other incentives to peak performance exist. One good example is a bonus/penalty provision common to many power purchase contracts. For example, if seasonal rates are paid for the output, then it is imperative that the plant operates well during the peak time of the year. A bonus for good operation, tied with a penalty for not meeting minimum performance requirements, helps ensure optimum performance and guarantees supply. Geothermal plants are most often designed to operate continuously year round, i.e., broad base load power. As a result, developers sell not only energy but capacity of their projects. Capacity requirements are met by operating a minimum period of time per year, e.g., 80 percent or 7,008 hours. Payments for plant capacity are based on meeting the agreed upon performance levels. Penalties may be invoked by both utilities and plant owners if such minimum performance levels are not met. Both developers and bankers count on 80 percent capacity levels for geothermal power plants, a figure consistently being beaten in actual operating results (see Kleinhans and Prideaux, 1985; Nichols, 1989).

The duration of O\&M contracts is usually less than the financing period. For example, Bankers Trust reports only one life of the financing O\&M contract. It was for a gasfired project, a relatively easy technology. The standard O\&M contract length is closer to five years (ASE,
July/August 1988). Another term consideration is time to first major maintenance; perhaps four to seven years, depending on technology. New geothermal plants typically schedule an inspection outage yearly (Kleinhans \& Prideaux, 1985), however, three years might be an appropriate major maintenance interval. Turbine and pipeline inspections, along with pump motor checks, are performed during 2 major maintenance.

Payment terms to O\&M contractors vary widely. Fixed fee, cost plus fixed fee, cost plus a percentage of fees, and firm price with escalation are all examples cited by Combustion Services, Inc., a subsidiary of Combustion Engineering (ASE, July/August 1988). As such information is typically proprietary, it is difficult to estimate terms common to the geothermal industry.

The actual cost of operating and maintaining a geothermal plant is similar to that for any power plant. A "bathtub curve" is cited by Combustion Services, Inc. as descriptive of this cost. The rate starts out high during the shakedown period, tapers down to a minimum as the plant begins to operate smoothly, and then goes up as parts start to wear out. Early experience with newly constructed geothermal plants indicates that their curve may not start out as high if design and operation is performed correctly (Kleinhans \& Prideaux, 1985).

As the independent power industry matures, as existing plants reach middle age, and as profit margins for new facilities become smaller, $0 \& M$ will be the key to an adequate income stream to meet financial responsibilities, contract terms, and to ensure the availability of future sources of funding for new projects. In addition, reliability will be the key to continued acceptance of independent power by both utilities and utility regulators.

\section{Regulation}

Complying with all laws and regulations is part of doing business. Reducing regulatory risk of power projects is simply the best way of doing business. To reduce such risk, one first has to know what regulations apply to the project. There are three main types of regulation facing geothermal and, to a lesser extent, other power plant developers: resource access, environmental regulation, and utility law. Once understood, complying with applicable laws and regulations is required. Financial backers of power plants frequently cited the use of lawyers to review project permits and licenses in order to keep regulatory risks to a minimum.

Resource access for geothermal resources is based on mineral law. Accessing and using geothermal energy is 
directly taken from fluid mineral development. The Geothermal Steam Act of 1970 (P.L. 91-581) and related state statutes provide for access to most lands. The Geothermal Steam Act was the first federal resource law passed after the passage of the National Environmental Policy Act of 1969 (NEPA) and because of this, reflects contemporary values and practices more than with any other natural resource. Private land access techniques draw from these laws. As a result, geothermal resources are leased or bought to secure access. They are subsequently drilled for and produced in a manner similar to oil and natural gas. Power generation occurs as in other generating plants, but "fuel" development is like oil field work. Therefore, developers must first lease or buy the resources from the landowner or holder of the proper rights. For a full discussion of this issue, see Bloomquist, et al., 1985. A valid lease is one of the first items obtained prior to development. Following a lease is an approved plan of operation by the responsible state or federal agency. Resource access risks are therefore reduced by confirming title to the resource and regulatory approval to develop it.

All power projects impact the air, land, and water near the plant site. With the advent of legislation protecting the environment in the 1970 s, both federal and state regulations that limit or mitigate such impacts have been put in place. The three best known examples are NEPA, the Clean Air Act of 1970, and the Water Pollution Control Act of 1972. Today, all power projects have required permits to allow mitigated impacts, e.g., Water Pollution Control Facility permits for waste disposal via injection. Much has been written on specific environmental impacts, mitigation techniques, and complying with regulations (see Bloomquist, et al., 1985). Financiers prefer "clean" resources that require minimum mitigation and/or cost of compliance. A pattern of mitigation by avoidance rather than treatment marks new geothermal plant designs. Secondly, regardless of resource quality, making sure all permits are in order is critical.

Similarly, with the passage of laws expanding the ability of non-utility businesses to generate and sell power, state and federal rules implementing such laws are also now in effect. The relevant laws are the Public Utility Regulatory Policies Act of 1978 (P.L. 95-617) and the Energy Security Act of 1980 (P.L. 96-223). Much has been written on this subject (see Sifford, Bloomquist, and Geyer, 1987). The critical point is that projects must now comply with these laws and related regulations in order to qualify for maximum benefits accorded to non-utility power plant developers.
Assuring that a plant is certified as a Qualified Small Power Production Facility by the Federal Energy Regulatory Commission is perhaps the best example of reducing such regulatory risk.

Once it is known exactly which laws, regulations, and resulting costs apply to their projects, developers can comply. Similarly, financial backers of power plants can confirm that all regulatory hurdles are cleared. Bankers backing projects frequently referred to legal review of all project permits and licenses to minimize regulatory risks. Consultants also operate in this field, advising developers much like consulting engineers and geologists do. Whether developers use consultants or lawyers, reducing regulatory risks is accomplished by obtaining and complying with all certifications, licenses, and permits. Assuring minimum regulatory risk is becoming more and more a prerequisite for obtaining financing and winning bids for power sales.

\section{Financiers of Geothermal Energy Projects}

\section{Introduction}

Representatives of several large commercial banks were interviewed in order to gain insight into the operations of their project finance activities. Specifically, details concerning geothermal and other energy resource project financings which these banks participate in were sought. Topics covered in the interviews included preferred project characteristics, financing terms, risk management techniques and evolving bank roles.

Interviews were conducted with the following persons:

Don Carse \& Cindy Jay

Vice President \& Assist. VP July 12, 1988

Bankers Trust Company

280 Park Avenue

New York, NY 10017

Ian Glenday \& Frank Hofman

July 13, 1988

First Vice President \& VP

Union Bank of Switzerland

299 Park Avenue

New York, NY 10171

David Barrick \& Jeff Riopelle

Vice President \& Assist. VP

Swiss Bank Corporation

4 World Trade Center

New York, NY 10008
July 13,1988 
Ray Weber

Manager, Business Development

General Electric Capital

1600 Summer St.

Stamford, CT 06905

Don Kyle

Vice President, Project Finance

Citibank, N.A.

399 Park Avenue

New York, NY 10043

Ann Lopez

March 22, 1989

Vice President

Credit Suisse

50 Califomia Street

San Francisco, CA 94111

These financial institutions were suggested by Stone and Webster Engineering Corp., who in the past has been retained by them to serve in an advisory capacity. Our intent was to obtain unpublished information about project financing. The banking community is understandably closed-mouthed about their work. "Tombstone" announcements found in the financial press are the only indicator of financings to outside parties. Such sources, however, indicate a tremendous growth in the field as shown in Table 4 (1986-1988). Market maturity is also confirmed by the number of participants, types of projects, and financing structures used.

\begin{tabular}{|c|c|}
\hline \multicolumn{2}{|c|}{ Alternate Energy Financings } \\
\hline 1986 & $\$ 2,700,000,000$ \\
\hline 1987 & $\$ 5,600,000,000$ \\
\hline 1988 & $\$ 4,800,000,000$ \\
\hline 1st Quarter 1989 & $\$ 3,275,000$ \\
\hline
\end{tabular}

The interview team represented BPA and the Washington and Oregon state energy offices previously documented Northwest geothermal resource potential, as well as legal and institutional environments. (Bloomquist et al, 1985) Financial community studies are the logical continuation of this work as capital investment is the driving force behind the development of alternative energy projects.

Since bankers generally don't publish papers detailing their projects, interviewing energy bankers on their own turf is the best means of obtaining current, comprehensive information. The effort provided a great deal of insight into the world of alternate energy financing, as discussed below.

The banks interviewed are among the largest in the world. Rankings in size for each bank, according to assets, are provided. The source is a September 23, 1988, Wall Street Journal special report.

In addition to the above listed financial institutions, the President of Citizen Energy, a Boston, Massachusetts, power marketing brokerage firm was also interviewed in July 1988.

\section{Common Elements}

The bankers interviewed are in the project finance groups of their respective companies. Project finance at the large commercial banks frequently evolved from urility/energy/natural resources groups. Today's changing bank structure indicates perceived market evolution: similarities among power projects have grown, while distinctions have diminished. Utilities no longer are the only parties building power plants (see Chapter 2). Many energy or natural resource projects (e.g., oil wells or mines) can be financed based not only on the applicants' credit worthiness, but on producible resources (supply) and sales contracts (market demand). A strong predictable cash flow supports project financing. So the type of project to be financed becomes less important than whether the proposal meets strict financial and performance criteria. These criteria are discussed at length below.

Much energy project financing is now characterized by non-recourse loans. A traditional mortgage-backed loan or line of credit arrangement is typically based on the sponsor's name or assets. Such loans provide the bank some collateral or source of repayment unrelated to project proceeds. These remain desirable as altemative payment sources for banks. In contrast, non-recourse loans are secured only by project collateral and cash flow. Such projects have little salvage value, so in many respects are backed simply by a collection of contracts. Should a project run into financial difficulties; the bank's only recourse is to take over and complete the project, then operate it or sell it. Developers would lose equity under those circumstances, but not assets unrelated to the project itself. As a result, only projects with guaranteed strong cash flows and minimal risks qualify for non-recourse project financing. The bank's incentive to participate in such 
financing is a combination of fees (advisory) and premium interest rates. Status as "lead bank" provides the greatest earnings and control, along with the opportunity to participate in new and promising markets/echnologies. Involvement may be as a "lead bank" or as a minority loan underwriter.

Each bank has similar financing terms and rates. This is no surprise as they frequently syndicate loans, thereby agreeing to the same terms. Competition also keeps rates close, but there is variance in terms for each project. Project finance loan periods are typically 5 to 12 years. Loan rates are the bank's cost of money plus some percentage. Rates are expressed in basis points ( 100 basis points $=1$ percent) over either the London Interbank Overseas Rate (LIBOR) or the prime U.S. rate. Small basis point differences result in big income variations due to the sums of money these banks work with. As bank costs to analyze and finance deals are not proportional to the loan size, major bank participation is timited to large, solid projects. Every bank interviewed suggested that loan amounts less than $\$ 15$ or $\$ 20$ million dollars should be handled by regional or local banks.

Another common element of geothermal project financing is the changing role of construction and long term debt financiers. Investment banks historically raised equity. Providing short term construction financing is traditionally a commercial bank function. Long term debt (or take-out financing) has been an insurance industry or pension fund role. The local scarcity and competitive nature of current lending opportunities is blurring these roles. Today, investment banks will occasionally boost equity participation to 100 percent and take the whole project private. Commercial banks now offer relatively long term. debt financing if needed, and aggressive insurance companies are now offering to provide both construction and long tem financing. Any of these traditional financiers, as well as independent finance corporations, will provide early advisory services in order to gain knowledge of and entre' to promising projects. Historical roles of financial institutions are changing and becoming more and more obscure due to a competitive market.

\section{Individual Perspectives}

\section{Bankers Trust Company}

Bankers Trust Company is headquartered in New York, and ranked 75th in the world in 1987. Bankers Trust Company is involved in the ORMESA ventures in California's Imperial Valley. The bank initially entered the project because of the availability of a USDOE Geothermal Loan Guarantee. The guarantee was negotiated for 90 percent project backing by Republic Geothermal Company and subsequently transferred to ORMESA partners. Bankers Trust likes the modular binary features of ORMAT Systems, Inc. units and the company's established track record. For all projects, Bankers Trust wants motivated participants with expertise in a particular area. Expanding energy project lending beyond just construction financing now appeals to Bankers Trust.

Bankers Trust emphasized the comfort level most banks seek using big name constructors and operators. The construction contract should be fixed price to reduce bank risk. To reduce operating risk, a performance warranty for some period following construction is best to motivate the developer.

Bankers Trust seemed acutely aware of western utility markets, particularly Pacific Gas \& Electric's historically negative attitude towards independent power producers. As a result, they do not simply accept a binding contract for the market. The bank wants to know two market attributes: first is the price for power so high as to be "off-market"; and second, would the purchasing utility accept a contract extension resulting from delays in the project? Both factors indicate whether the utility would be flexible about renegotiating the contract or would seize the opportunity to kill the project.

\section{Unton Bank of Switzerland}

Union Bank is headquartered in Zurich, Switzerland, and ranked 27th in the world in 1987. Union Bank of Switzerland participated in both the Magma (Salton Sea) and Oxbow (Dixie Valley) project financings. This bank likes flash technology, but investigated binary technology as well. Union Bank wants proven reservoirs, experienced developers and zero regulatory risk. They expressed no tolerance for local controversy over projects. Of course, a large equity position by the developer helps offset developer inexperience, e.g., Oxbow Geothermal, and reduce the bank's exposure.

Union Bank has much experience in offshore oil and gas financings, which leads it to want a proven reservoir before lending. It views power plant development as akin to step out oil field development: some major work by the developer must be completed before approaching the bank. The equipment and operator should have proven track records, even if the name is not the biggest in the field. 
Union Bank also balances risk and reward by syndicating loans (not keeping the entire amount on its books). Dividing loans among syndicates of other banks spreads both costs and benefits. Union Bank seeks quality projects via involvement with respectable, familiar entities, e.g., utility subsidiaries, engineering firms and contractors. Risk is reduced through these techniques.

\section{Swiss Bank Corporation}

Swiss Bank Corp. is headquartered in Basel, Switzerland, and was ranked 30th in the world in 1987. Swiss Bank Corporation started geothermal work funding the Northern California Power Agency buy-out of its supplier's leases at The Geysers. The credit worthiness of the public entities behind the NCPA project made it a relatively risk free project. NCPA members include the cities of Santa Clara and Ukiah, Modesto Irrigation District, and the Sacramento Municipal Utility District. The project had operated for some time before Swiss Bank financed the leasehold purchase. It has subsequently participated in the Oxbow (Dixie Valley) and Yankee-Caithness (Steamboat Springs) projects, in a syndicate and as sole banker, respectively. This bank also likes flash technology, and has investigated binary systems. Dry steam is preferred, however, where available. The Yankee-Caithness project ( $\$ 9$ million) was below Swiss Bank, and every other bank's, minimum loan amount but was done to build relationships.

Swiss Bank likes clean resources to satisfy regulators and to keep both capital and operating costs down. It is sensitive to injection requirements and to site decommissioning procedures. Tight construction and $\mathrm{O \& M}$ contracts are also part of Swiss Bank's normal operating process. The bank retains both New Yotk lawyers and project-specific local attomeys to reduce market and regulatory risks. Swiss Bank hires good consulting engineers, i.e., Stone \& Webster, and has some in-house engineering capability.

Unlike other banks, Swiss Bank will not automatically sell parts of loans, but instead keeps some entirely on its own books. It also likes the lead bank role, for both growth and status. Because of its NCPA experience, publiclybacked opportunities appeal to it, regardless of technology or resource. A good example of Swiss Bank's ideal opportunity is a county-sponsored waste-to-energy project.

\section{Citbank}

Citibank is headquartered in New York and ranked 8th in the world in 1987. Citibank was lead agent for the $\$ 110$ million Oxbow (Dixie Valley) project financing. As a buge player in both the oil and utility financing markets, Citibank moved into geothermal knowledgeably yet cautiously. Citibank is the only bank interviewed with its own staff of reservoir engineers. These engineers, based in Denver, are experienced in oil and gas field assessment. The New Yotk staff therefore concentrates on technology (flash version binary) and financial analysis.

Operating and maintenance contracts are most important to Citibank along with construction completion guarantees. The bank wants authorization to replace the O\&M contractor if necessary. Citibank also raised the same utility flexibility issue that Bankers Trust did, referring to "cram down rates" in contracts. Bankers Trust called them "off market" but both terms refer to power purchase rates at premium prices.

Citibank believes it is the leading utility bank, commanding 25 percent of the $\$ 3.5$ billion annual market. Independent power projects are just an extension of that business, which Citibank intends to also lead. Ciubank indicated that packaging total project financing with debt, equity, and commercial paper is another of its special attributes. Citibank also is active in interest rate "swaps," which help commercial banks enter into longer term commitments.

\section{General Electric Capital}

General Electric Capital, formerly GE Credit Corp., is headquartered in Stanford, Connecticut. GE is not a bank, but it functions like one when financing energy projects. GE Capital clearly wants early participation in projects, typically before a bank would become involved. In return, GE Capital expects higher rates of return than a bank. GE Capital wants developers to use GE turbine generators, and tries to steer equipment selection to General Electric, but this is not a requisite to financing. Despite a greater tolerance for risks, GE Capital's bad loan rate of about 2 percent for energy projects is quite comparable to those of commercial banks.

The only geothermal project GE Capital financed is the Heber flash plant. GE Capital provided construction financing and a long term leveraged lease for the project. Geothermal supply problems at Heber have made GE Capital cautious of geothermal, and they would seek outside consulting advice to assure reservoir adequacy before financing future projects. The Heber situation points to the Citibank emphasis on fuel deliverability, not just reservoir size. In similar energy projects using gas fired cogeneration, GE Capital strongly considers fuel supplies. GE reduces cogeneration fuel risks by securing gas fields in Canada and 
Texas to assure supply and participated in the financing of gas pipelines to assure access.

GE Capital will go to greater leveraging in deals, e.g., 99 percent debt. This is due to its desire to get in early and receive higher rates of retum than a bank. GE Capital believes it is much more flexible than any bank, and acknowledges that it is more expensive as a result. The difference in philosophy between GE Capital and banks is the approach to failure: GE plays to win as opposed to banks playing not to lose. GE Capital's competitors, in its eyes, are therefore not banks but aggressive subsidiaries of insurance companies and utilities. Prudential Capital with over $\$ 1.7$ billion in $\mathbf{5 8}$ alternative energy project financings, is the chief competitor.

\section{Credit Sulsse}

Credit Suisse is headquartered in Zurich, Switzerland, and ranked 44th in the world in 1987. Credit Suisse participated in three geothermal projects: the California Energy Company project at Coso Hot Springs, Califomia; the Oxbow Project in Dixie Valley, Nevada; and in ORMAT's Imperial Valley project. The bank is lead agent for the first project, and part of a syndicate in the latter two projects. It is the California Energy Company project that distinguishes this bank among others. Credit Suisse came into the geothermal energy financing business indirectly. Both the loans and loan officer originated at Crocker Bank, went to Wells Fargo, via a buy-out, then arrived at Credit Suisse. Credit Suisse purchased its first geothermal loans from Wells Fargo, then originated further project loans at the Coso project with the same developer. As a result, the developer, market, resource, and technology are the same for the bulk of its geothermal loans.

The Coso project is actually three plants comprised of nine units totaling $230 \mathrm{MW}$. Credit Suisse issued four project finance loans totaling $\$ 468$ million. Loan proceeds apply to power plants, gathering systems, and transmission lines. The plant loans are to be repaid over a nine to ten year period after completion of construction. Interest on the loans varies from 1 to 3 percent over LIBOR.

Credit Suisse has less firm rules than other banks as to what a developer should bring to the table, except to satisfy its "comfort level." So, for example, no set nules on equity participation are applied, but close attention is paid to what amount of debt will the project support. The equity proportion is evaluated against this finding. One way Credit Suisse satisfies their "comfort level" is to have the developer maintain production capacity of 125 percent of the geothermal resources necessary to operate the power plants. Other ways are special cash accounts for well replacement and contingencies, and project control accounts for all revenues.

Credit Suisse sees a big future market for independent power projects. Geothermal projects present a less clear. picture. Competition between banks is seen as a growing trend. Credit enhancers, e.g., letters of credit backing bonds, will be more commonly used in new projects as a means of improving economics.

\section{Conciusions}

The financial organizations interviewed by the authors represent the upper echelon of independent energy backers. Projects they finance are characterized by the following:

- Large loans, \$15-20 million minimum;

- Managed by the bank's project finance group;

- Typically non-recourse and high risk in nature;

- Have loan lengths ranging from 2 to 12 years;

- Have interest rates of $0.75-3.0$ percentage points over LIBOR or the prime rate, plus loan fees and, perhaps, advisory service fees;

- Using the best consulting geothermal engineers to assure both reservoir and equipment performance;

- Using equipment and suppliers that are well known;

- Using operators and performance guarantees that assure reliable operation over the long haul.

- Syndicated loans, (mostly), to spread the risk around;

- Foreign bank participation based primarily on the fundamentals; and

- American bank participation based on fundamentals plus familiarity with utility markets and attitudes.

In conclusion, the banks and other financial groups backing these projects have now achieved sufficient familiarity with altemative energy projects brought to the table by independent power producers to back these projects and make money from doing so. They did this by merging their natural resource and utility banking experiences. What remains to be done is assuring long term operation to gain credibility and put to rest any reliability questions. This will be an increasing requirement of the utilities as they become more dependent upon independent power producers for an ever increasing portion of their load. Independent geothermal developers are meeting financiers' expectations. 


\section{References}

Ajello, J.E., and D.I. Fellman, 1986, "The Development of Altemative Generation Sources in California," Productivity Through Energy Innovation, Proceedings of the third Great PG\&E Energy Expo, pp. 616-623, Pergammon Press, Elmsford, NY.

Alper, R.D., 1987, "The Status of Proceedings at the Public Service Commission of Nevada Regarding Geothermal Energy Development," Geothermal Resources Council Transactions Vol. 11, Davis, CA.

Alternative Sources of Energy, 1988.

Anderson, J., 1986, Personal Communication.

Asper, W.E., 1985, Personal Communication.

Asper, W.E., 1986, Personal Communication.

Asper, W.E., 1988, Personal Communication.

Bain, D., 1989, Development Framework for PURPA Resources in Oregon, ODOE, Salem, OR, under Bonneville Power Administration contract DE-AI7987BP66141.

Benoit, D., 1987, Personal Communication, Oxbow Geothermal Co.

Blachly, D., 1985, Personal Communication.

Bloomquist, R.G.; G.L. Black; D.S. Parker; A. Sifford; S.J. Simpson; and L.V. Street, 1985, Evaluation and Ranking of Geothermal Resources for Electrical Generation or Electrical Offset in Idaho, Montana, Oregon, and Washington, Washington State Energy Office, Olympia, WA, 504 pp.

Budd, C., 1973, "Steam Production at The Geysers Geothermal Field," Geothermal Energy Resources, Production and Stimulation, Kruger and Otte, editors, Stanford University Press, Stanford, CA.

Buenger, C., Dow Chemical, 1989, Personal Communication.
Campbell, R.G. and B. Holt, 1985, Design, Construction, and Operation of the Mammoth Geothermal Power Plants, Electric Power Research Institute, Ninth Annual Geothermal Conference and Workshop.

Cerini, DJ.; C.P. Dipple; and W.C. Gonser, 1984, "Project Development Desert Peak 9 MW Power Plant," Geothermal Resources Council Transactions, Vol. 8, pp. 33-39.

Dipple, C.P. and W.C. Gonser, 1985, "Project Development Desert Peak," Geothermal Resources Council Transactions, Vol. 9, Part II, pp. 127-131.

Fesmire, V.R., 1985, "Reliability Through Design, the Santa Fe Geothermal Plant No 1," Geothermal Resources Council Transactions, Vol. 9, Part 11, pp. 133-137.

Fontes, R.A., 1985, "NCPA Geysers Geothermal Development of Integrated Steam Field Management Systems," Proceedings of Geothermal Topical Review, "Geothermal Development at The Geysers," U.S. Department of Energy, pp. 415-420.

Independent Power Report, February and June 2, 1989, McGraw-Hill Inc., New York, New York.

Kellerman, L., Citizens Power and Light, 1989, Personal Communication, Boston, MA.

Kleinhans, P.V. and D.L. Prideaux, 1985, Design, Startup, and Operation of SMUDGEO \#1, P.C.E.A. Annual Engineering and Operating Conference, TP 85-6.

Ludolph, J., 1985, Personal Communication.

Lyster, D., 1985, Personal Communication, Mammoth, CA.

MacPhee, T., 1987, "Reduction of Hydrogen Sulfide Emissions from Geothermal Steam by the Use of a Computer Control System," Geothermal Resource Transactions, Vol. 11, pp. 445-451.

McClain, D., California Energy Co., 1989, Personal Communication, San Francisco, CA. 
McKay, G.D. and R.E. Tucker for Stone \& Webster, 1985, Integrating Geothermal Power Plant Design with Steam Field Operation for an $80 \mathrm{MW}$ Plant in The Geysers, EPRI/IIE Geothermal Conference and Workshop.

Meade, W.R. and K.L. Porter, 1987, "Trends in State Utility Regulation Affecting Renewable Energy," Renewable Energy Institute, Washington D.C.

Miller, ORMAT System Inc., 1987, Personal Communication.

Miller, ORMAT System Inc., 1988, Personal Communication, Sparks, NV.

Miller, ORMAT System Inc., 1989, Personal Communication.

Moore, J.L., 1986, Personal Communication.

NAESCO, 1988, National Association of Energy Service Companies, in Cogeneration Report, April, 22, 1988 and July 29, 1988, McGraw-Hill Inc., New York, NY.

Nelson, T.T., 1985, "Heber Binary Project," Geothermal Resources Council Transactions, Vol. 9, Part II, pp. 161-165.

Nichols, K., 1989, Personal Communication.

ORMAT, 1989, Small Power Plant Update, Geothermal Resources Council, Reno, NV.

Oxbow Geothermal Corp., 1986, Docket No. EL 86-30-00, Federal Energy Regulatory Commission, Washington, DC.

Pacific Gas \& Electric Company, 1987, "Cogeneration and Small Power Production Quarterly Report," Fourth Quarter 1987, San Francisco, CA.

Prideaux, D.L., 1985, Personal Communication.

Rosser, J., California Energy Company, 1989, Personal Communication.
Sifford, A., R.G. Bloomquist, J. Geyer, 1987, "PURPA Influence on Contemporary Geothermal Power Plants," Geothermal Resources Council Transactions, Vol. 11, Davis, CA.

Sones, R., 1985, Personal Communication.

Southern Califormia Electric Company, 1987, "Cogeneration and Small Power Projects Quarterly Report," Fourth Quarter 1987, Rosemead, CA.

Stoiaken, L., 1988, "Staying in the Race," Alternative Sources of Energy, July/August 1988, Milaca, MN.

Stone \& Webster Engineering Corp., 1985, Personal Communication, Denver, $\mathrm{CO}$.

Tucker, R.E.; P.V. Kleinhans; and L.R. Keilman, 1980, "SMUDGEO \#1 Economic Impacts on Geothermal Power Plant Design," Geothermal Resources Council Transactions, Vol. 4, pp. 533-536.

Tucker, R.E.; J.F. Laur; and B.J. Beal, 1985, "Centrifugal Compressors: Key to Efficient Noncondensible Gas Removal for Geothermal Applications," Geothermal Resources Council Transactions, Vol. 9, Part II, pp. 201-205.

U.S. Department of Energy, 1981, Inventory of Power Plants in the United States 1980 Annual, DOE/EIA CO95 (80), Washington, DC.

Washington State Energy Office, 1989, Power Sales to Electric Utilities-PURPA Qualifying Facility Developer in Washington State, Olympia, WA, 105 pp.

Weber, R., 1988, General Electric Capital, Personal Communication, Stamford, CT.

Yahalom, Y., Ormat System, Inc., 1987, Personal Communication, Sparks, NV.

Yueh, D.D., 1986, Personal Communication. 